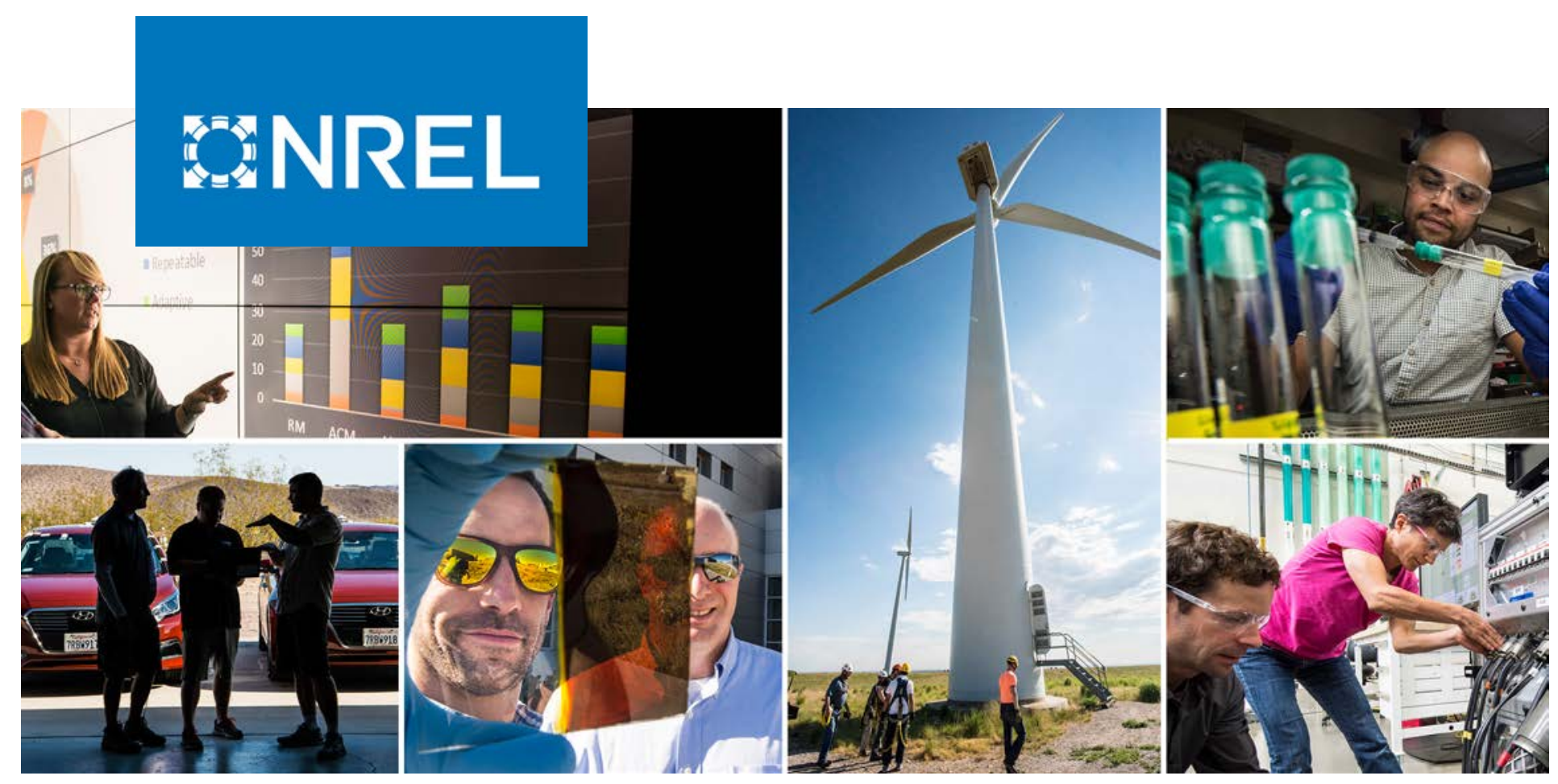

\title{
Clean Cities Coalitions 2018 Activity Report
}

Mark Singer and Caley Johnson

National Renewable Energy Laboratory

NREL is a national laboratory of the U.S. Department of Energy

Office of Energy Efficiency \& Renewable Energy

Operated by the Alliance for Sustainable Energy, LLC

This report is available at no cost from the National Renewable Energy Laboratory (NREL) at www.nrel.gov/publications.

\section{Technical Report}

NREL/TP-5400-75324

December 2019 


\section{GNREL}

\section{Clean Cities Coalitions 2018 Activity Report}

Mark Singer and Caley Johnson

National Renewable Energy Laboratory

\section{Suggested Citation}

Singer, Mark and Caley Johnson. 2019. Clean Cities Coalitions 2018 Activity Report.

Golden, CO: National Renewable Energy Laboratory. NREL/TP-5400-75324.

https://www.nrel.gov/docs/fy20osti/75324.pdf.

NREL is a national laboratory of the U.S. Department of Energy Office of Energy Efficiency \& Renewable Energy Operated by the Alliance for Sustainable Energy, LLC

This report is available at no cost from the National Renewable Energy Laboratory (NREL) at www.nrel.gov/publications.

Contract No. DE-AC36-08GO28308
Technical Report NREL/TP-5400-75324

December 2019

National Renewable Energy Laboratory 15013 Denver West Parkway Golden, CO 80401 303-275-3000 • www.nrel.gov 


\section{NOTICE}

This work was authored by the National Renewable Energy Laboratory, operated by Alliance for Sustainable Energy, LLC, for the U.S. Department of Energy (DOE) under Contract No. DE-AC36-08GO28308. Funding provided by the U.S. Department of Energy Office of Energy Efficiency and Renewable Energy Vehicle Technologies Office. The views expressed herein do not necessarily represent the views of the DOE or the U.S. Government.

This report is available at no cost from the National Renewable Energy Laboratory (NREL) at www.nrel.gov/publications.

U.S. Department of Energy (DOE) reports produced after 1991 and a growing number of pre-1991 documents are available free via www.OSTI.gov.

Cover Photos by Dennis Schroeder: (clockwise, left to right) NREL 51934, NREL 45897, NREL 42160, NREL 45891, NREL 48097, NREL 46526.

NREL prints on paper that contains recycled content. 


\section{Table of Contents}

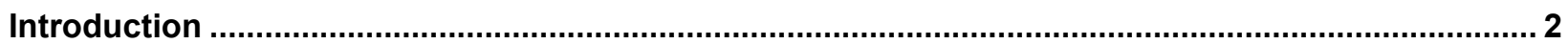

Summary of Key Findings......................................................................................................... 3

Attribution and Fuel Use Factors ........................................................................................... 5

Coalition-Reported Data ............................................................................................................... 5

Alternative Fuels and Vehicles................................................................................. 5

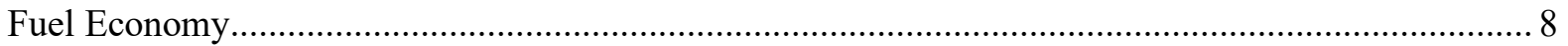

Vehicle Miles Traveled Reduction ................................................................................. 9

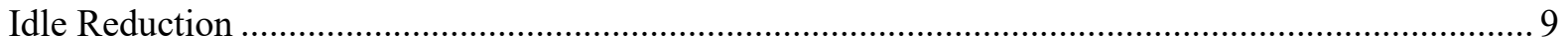

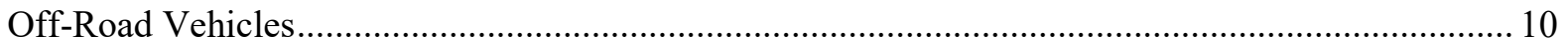

National Clean Fleets Partnership Contributions ................................................................. 11

Estimated Contributions from Outreach Activities ..................................................................... 12

Methods Used to Estimate Energy Use Impact from Outreach Activities .................................... 12

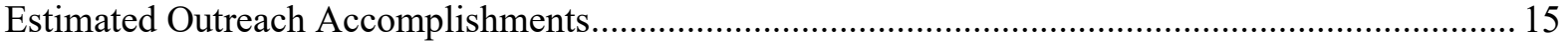

Cumulative Energy Use Impact ............................................................................................... 17

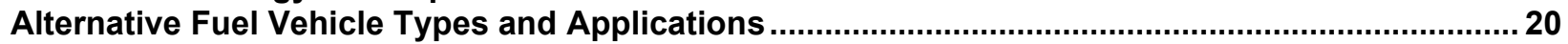

Emerging Technologies_Experimental, Prototype, and Demonstration Vehicle Projects ................ 22

Coordinators and Coalition Types .......................................................................................... 22

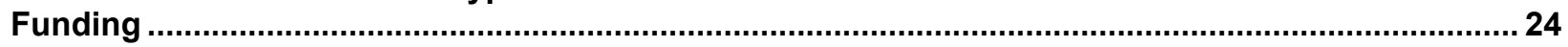

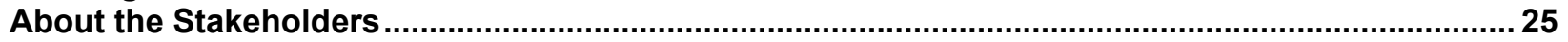

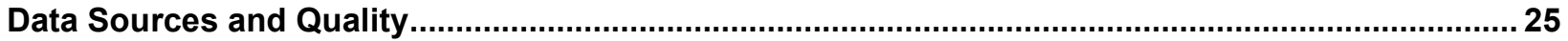

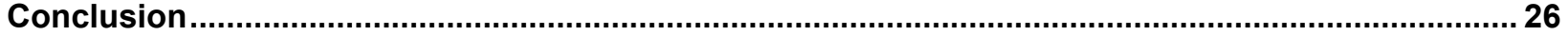

Appendix A: Clean Cities Coalitions that Completed 2018 Annual Reports ...................................27

Appendix B: Definition of Clean Cities Coalition Types ......................................................... 30 


\section{List of Figures}

Figure 1. 2018 percentage of alternative fuel vehicles (AFV), energy use impact (EUI), and emissions reductions by fuel type.

Figure 2. Average energy saved per vehicle for 2018 Clean Cities coalition fuel economy projects ........... 8

Figure 3. Energy savings measured in million gasoline gallon equivalents (MGGE) from idle reduction

(IR) projects, 2018

Figure 4. Percentage of outreach activities reaching each audience type ............................................ 16

Figure 5. Percentage of outreach activities by technology type.................................................... 17

Figure 6. Increasing energy use impact (EUI) from coalitions ....................................................... 18

Figure 7. Cumulative accomplishments of all Clean Cities coalition activities....................................... 19

Figure 8. Cumulative emissions reductions from all Clean Cities coalition activities..............................2 20

Figure 9. Alternative fuel vehicles (AFVs) by vehicle and fuel type ................................................ 21

Figure 10. Alternative fuel vehicles (AFVs) by application and fuel type ........................................... 22

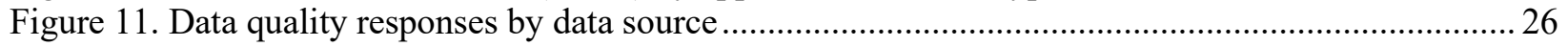

\section{List of Tables}

Table 1. Energy Use Impact (EUI) of Each Portfolio Element.............................................................. 3

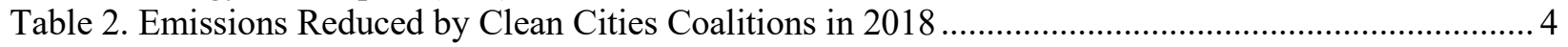

Table 3. Average Annual Energy Use Impact (EUI) per Vehicle in 2018 .............................................. 7

Table 4. Vehicle Miles Travelled (VMT) Reduction Project Types, Number, and Energy Savings in 2018

Table 5. Number of Off-Road Vehicles or Equipment and Energy Use Impact (EUI) in 2018 ................ 11

Table 6. Vehicles, Energy Use Impact (EUI), and Emissions Reduction from National Partners ............. 12

Table 7. Benchmark Customer Conversion Rates and Their Sources .................................................... 13

Table 8. Relationships for Media Effectiveness and Their Sources ...................................................... 14

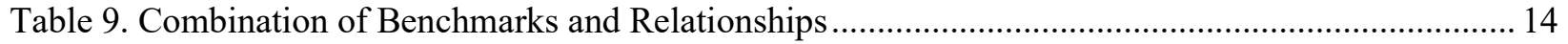

Table 10. Customer Conversion Rates Used in the Behavior Impact Model (BIM) ............................... 15

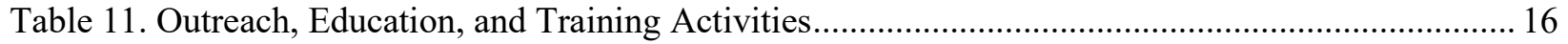

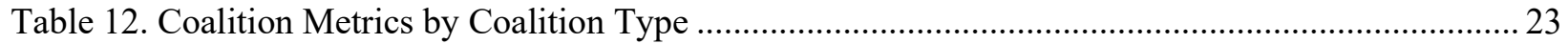

Table 13. Breakdown of 2017 Project Awards by Number and Value .................................................... 24 


\section{List of Acronyms}

$\begin{array}{ll}\text { AFDC } & \text { Alternative Fuels Data Center } \\ \text { AFV } & \text { alternative fuel vehicle } \\ \text { CNG } & \text { compressed natural gas } \\ \text { BIM } & \text { Behavioral Impact Model } \\ \text { DOE } & \text { U.S. Department of Energy } \\ \text { E85 } & \text { high-level ethanol blend } \\ \text { EUI } & \text { energy use impact } \\ \text { EV } & \text { all-electric vehicles } \\ \text { GGE } & \text { gasoline gallon equivalent } \\ \text { GHG } & \text { greenhouse gas } \\ \text { GREET model } & \text { Greenhouse gases, Regulated Emissions, and } \\ & \text { Energy use in Transportation model } \\ \text { HDV } & \text { heavy-duty vehicle } \\ \text { HEV } & \text { hybrid electric vehicle } \\ \text { IR } & \text { idle reduction } \\ \text { LDV } & \text { light-duty vehicle } \\ \text { LNG } & \text { liquefied natural gas } \\ \text { MGGE } & \text { million GGE } \\ \text { NCFP } & \text { National Clean Fleets Partnership } \\ \text { NREL } & \text { National Renewable Energy Laboratory } \\ \text { PEV } & \text { plug-in electric vehicle } \\ \text { RNG } & \text { renewable natural gas } \\ \text { VMT } & \text { vehicle miles traveled } \\ \text { VTO } & \text { Vehicle Technologies Office } \\ & \end{array}$




\section{Acknowledgements}

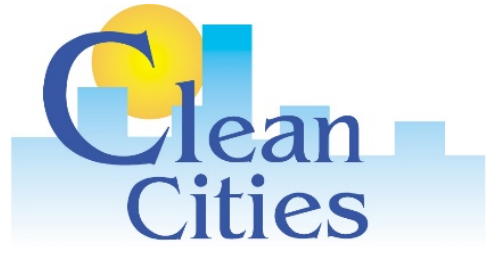

U.S. Department of Energy

The authors would like to acknowledge the efforts of thousands of Clean Cities coalition stakeholders and coordinators, who provided the basis for this analysis by reporting data from their alternative fuel and energy-saving transportation projects.

This work was supported by the U.S. Department of Energy (DOE) under Contract No. DE-AC36-08GO28308 with Alliance for Sustainable Energy, LLC, the Manager and Operator of the National Renewable Energy Laboratory.

This publication is part of a series. Past Clean Cities Coalitions Activity Reports and multiyear data compilations can be found at www.afdc.energy.gov. 


\section{Introduction}

The U.S. Department of Energy's (DOE) Office of Energy Efficiency and Renewable Energy's Vehicle Technologies Office (VTO) works with local Clean Cities coalitions across the country as part of its Technology Integration Program. These efforts help businesses and consumers make smarter/more-informed transportation energy choices that can save energy, lower costs, reduce reliance on imported oil, and reduce emissions. This report summarizes the success and impact of coalition activities based on data and information provided in their annual progress reports.

A national network of nearly 100 Clean Cities coalitions, whose territory covers more than $80 \%$ of the U.S. population, brings together stakeholders in the public and private sectors to use alternative and renewable fuels, idle-reduction (IR) measures, fuel economy improvements, and new transportation technologies as they emerge. To ensure success, coalitions leverage a robust set of expert resources and tools provided by National Laboratories and DOE. From technical assistance and handbooks to websites and targeted analysis, these resources contribute to every facet of coalition success. This strong national framework of resources, which facilitates consistent vision and informed coalitions, is a hallmark of the program.

Each year, Clean Cities coordinators submit annual reports of their activities and accomplishments for the previous calendar year. Data and information are submitted via an online reporting tool that is maintained as part of the Alternative Fuels Data Center (AFDC) at the National Renewable Energy Laboratory (NREL). Coordinators submit a range of data that characterize the membership, funding, projects, and activities of their coalitions. They

Clean Cities coalitions use an online tool to report advanced vehicle technology activity, infrastructure development, and relevant energy/fuel use information for their regions. also submit data about sales of alternative fuels; use of alternative fuel vehicles (AFVs), electric vehicles (EVs), plug-in electric vehicles (PEVs), and hybrid electric vehicles (HEVs); IR initiatives; fuel economy improvement activities; and programs to reduce vehicle miles traveled (VMT).

This report compiles the accomplishments of all coalitions throughout the nation in calendar year 2018. Coalition leaders assembled the data based on voluntary reports from their stakeholdersthe private and public entities that are members of the coalitions. As such, each of these coalition reports represents a subset of Clean Cities coalition activities. Taken together, they are an important indicator of how data, information, and resources can be effectively leveraged through the national network of Clean Cities coalitions and stakeholders, to achieve significant results. Accomplishments from the National Clean Fleets Partnership (NCFP) are also reported directly by the national partners.

NREL analyzes the submitted data to determine how broadly energy use in the United States has shifted as a result of coalition activities. The two main components of energy use tracked by NREL are (1) energy savings from efficiency projects, measured in gasoline gallon equivalents (GGE), and (2) alternative fuel use. The alternative fuel use numbers in this report have been adjusted to account for any gasoline or diesel content (e.g., with biodiesel or ethanol blends) as well as for any conventional fuels used upstream to produce, distribute, or deliver alternative 
fuels. Efficiency differences between AFVs and conventional vehicles are also taken into account. ${ }^{1}$ Ultimately, these two components are combined and reported as energy use impact (EUI) in GGE. EUI is a metric that measures combined progress in both energy savings from efficiency projects and increased fuel diversity, through use of domestic alternative fuels. Both these components provide consumers and businesses with more energy choices. When achieved at scale, these strategies support DOE's mission to pursue more secure, reliable, and affordable energy choices. This report summarizes EUI as well as the related emission reduction impacts of coalition activities.

A compilation of data from this report, along with reports from previous years, can be accessed on the AFDC's Maps and Data page (afdc.energy.gov/data/categories/clean-cities). Previous years' reports can be downloaded in their entirety at www.afdc.energy.gov.

\section{Summary of Key Findings}

Clean Cities coalition activities resulted in an EUI of over 1 billion GGE, comprised of net alternative fuels used and energy savings from efficiency projects, in 2018. Table 1 represents the combined results of all strategies to increase fuel diversity and energy efficiency in the nation's fleets. Participation in vehicle and infrastructure development projects remained strong, as did alternative fuel use and resulting overall EUI.

Table 1. Energy Use Impact of Each Portfolio Element

\begin{tabular}{|c|c|c|c|}
\hline Project Type & $\begin{array}{r}\text { Coalition Impact } \\
\text { (MGGE') }\end{array}$ & $\begin{array}{l}\text { Percent of Total } \\
\text { Coalition Impact }\end{array}$ & $\begin{array}{r}\text { Change from } \\
\text { Last Year }\end{array}$ \\
\hline Alt. Fuels and Vehicles & 744.4 & $70 \%$ & $+2 \%$ \\
\hline Fuel Economy & 53.9 & $5 \%$ & $+24 \%$ \\
\hline HEVs & 51.9 & $5 \%$ & $-9 \%$ \\
\hline EVs \& PHEVs & 45.0 & $4 \%$ & $+71 \%$ \\
\hline Idle Reduction & 42.9 & $4 \%$ & $-3 \%$ \\
\hline VMT Reduction & 31.3 & $3 \%$ & $+9 \%$ \\
\hline Off-Road & 17.8 & $2 \%$ & $+19 \%$ \\
\hline $\begin{array}{l}\text { Estimated Outreach } \\
\text { Impact }\end{array}$ & 69.1 & $7 \%$ & $+151 \%$ \\
\hline Total EUIc & $1,056.3$ & $100 \%$ & $+9 \%$ \\
\hline
\end{tabular}

${ }^{1}$ Net alternative fuel used, and energy savings from efficiency projects, in this report are expressed in GGE, using the lower heating value ratio of the fuels. 
Clean Cities coalition activities reduce emissions as they impact energy use. Table 2 shows that coalition-reported activities prevented 5 million carbon dioxide-equivalent tons of emissions (only greenhouse gas [GHG] emissions are reported here; criteria pollutants and other emissions are not included in this report).

Overall coalition EUI of over 1 billion GGE is the highest since the coalitions began reporting in 1994.

Table 2. Emissions Reduced by Clean Cities Coalitions in 2018

\begin{tabular}{|l|r|r|r|}
\hline Project Type & $\begin{array}{r}\text { Tons of GHG } \\
\text { Emissions } \\
\text { Averted }\end{array}$ & $\begin{array}{r}\text { Equivalent of } \\
\text { Conventional } \\
\text { Cars Removed }\end{array}$ & $\begin{array}{r}\text { Percent of } \\
\text { Coalition } \\
\text { Total }\end{array}$ \\
\hline $\begin{array}{l}\text { Alternative Fuels and } \\
\text { Vehicles }\end{array}$ & $2,121,677$ & 474,908 & $42 \%$ \\
\hline Fuel Economy Improvements & 667,531 & 149,417 & $13 \%$ \\
\hline HEVs & 639,899 & 143,232 & $13 \%$ \\
\hline Idle Reduction & 526,730 & 117,901 & $11 \%$ \\
\hline VMT Reduction & 385,883 & 86,375 & $8 \%$ \\
\hline EVs and PHEVs & 210,898 & 47,206 & $4 \%$ \\
\hline Off-Road Vehicles & 116,505 & 26,078 & $2 \%$ \\
\hline Outreach Events Estimate & 343,416 & 76,869 & $7 \%$ \\
\hline \hline Coalition Total & $5,012,539$ & $1,121,987$ & $100 \%$ \\
\hline
\end{tabular}

${ }^{\text {a }}$ Calculated as total passenger car GHG emissions (Table 2-13 in the U.S. Environmental Protection Agency's Inventory of GHG Emissions and Sinks:1990-2015) divided by total short wheelbase light-duty vehicles (Table VM1 in the Federal Highway Administration's Highway Statistics, 2015).

Coalitions were successful in securing project grant awards from numerous (non-DOE) outside sources. For other federal, state, and local agencies and private sector foundations, see funding section on page 24 . The 84 project grant awards in 2018 generated $\$ 251$ million in funds from coalition members and project partners in addition to $\$ 1.9$ million in DOE grant funds. Coalitions also collected $\$ 1.1$ million in stakeholder dues and \$2.9 million in operational funds from host organizations. In macro terms, this supplemental funding represents nearly a 7:1 leveraging of the \$37.8 million that was included in the VTO Technology Integration budget in Fiscal Year 2018.

Clean Cities coordinators spent nearly 121,000 hours pursuing their coalitions' goals in 2018. The average coordinator is quite experienced and has held his or her position for at least 8 years. Coordinators logged more than 3,805 outreach, education, and training activities in 2018, which reached an estimated nearly 36 Coalitions conducted 3,805 outreach, education, and training activities in 2018. million people. 


\section{Attribution and Fuel Use Factors}

To clarify the link between coalition activities and end results, this Clean Cities Coalitions Activity Report includes an attribution factor that accounts for the percentage of a project's outcome that may be a result of coalition activities, rather than the activities of other project participants. This attribution factor was used in the estimates of impacts for fuel economy, VMT reduction, IR, alternative fuel use, and outreach projects. Coordinators estimated the percentage of each project's outcome that the coalition was responsible for, then the project's overall outcome was multiplied by that percentage to determine the individual coalition's impact. Although subjective, this method attempts to address the issue of attribution where a coalition is one of several partners involved in a project. To reduce the subjectivity of this factor, NREL provides a tool to help a coalition estimate its contribution to a given project.

\section{Coalition-Reported Data}

Coordinators submitted information about their stakeholders' alternative fuel use and energy savings, broken down according to the technologies in the Technology Integration portfolio, using an online reporting tool. NREL analyzed the data, converted it into an equivalent net quantity of gasoline for each element of the portfolio, and reported the data in units of GGE - the amount of energy contained in a gallon of gasoline. As shown in Table 1, Clean Cities coalition efforts impacted 1,056 million GGE (MGGE) of energy in 2018.

Clean Cities coalitions' work with local fleets led to a substantial reduction in emissions. To estimate the GHG reductions resulting from coalition activities, NREL used a variation of the GREET model. ${ }^{2}$ This model accounts for the fuel life-cycle, or "well-to-wheels" factor of GHG emissions for transportation fuels, which includes fuel production, transport, and usage in the vehicle. It does not consider emissions from indirect land use changes or vehicle manufacturing.

\section{Alternative Fuels and Vehicles}

As shown in Figure 1, alternative fuels (used in AFVs and in biodiesel blends) and fuel savings from HEVs collectively accounted for approximately 841 MGGE, or $85 \%$ of the coalitionreported net alternative fuel use and energy savings from efficiency projects.

In 2018, coalitions reported a total inventory of nearly 950,000 AFVs, split among 10 fuel and technology types.

Coordinators reported large increases in some vehicle technologies. PEVs grew by $40 \%$ and represented the second largest vehicle fuel type in 2018 at 227,854 PEVs. The number of vehicles using renewable diesel grew by $43 \%$ to 11,000 vehicles. Hydrogen vehicles grew from a small base by $247 \%$ to 402 vehicles.

PEVs grew by $40 \%$ in 2018 and are now the second largest group of vehicles by fuel type.

The EUI from the use of PEVs increased 71\%. Other technologies with large increases in EUI include hydrogen at $528 \%$, renewable diesel at $28 \%$, biodiesel at $24 \%$, and renewable natural gas

\footnotetext{
${ }^{2}$ Argonne National Laboratory. 2015. The Greenhouse gases, Regulated Emissions, and Energy use in Transportation (GREET) Model.
} 
(RNG or bio-methane) at $23 \%$. The EUI associated with propane use increased by $18 \%$ while the number of propane vehicles decreased by $27 \%$.

Figure 1 shows the percentage of EUI according to fuel type. Compressed natural gas (CNG) remains at the top of the list, accounting for $49 \%$ of the EUI, even though only $9 \%$ of the total vehicle population uses CNG. This contrasts with E85, a high-level ethanol blend, which accounts for only $8 \%$ of the AFV EUI, although $28 \%$ of reported AFVs can use E85.

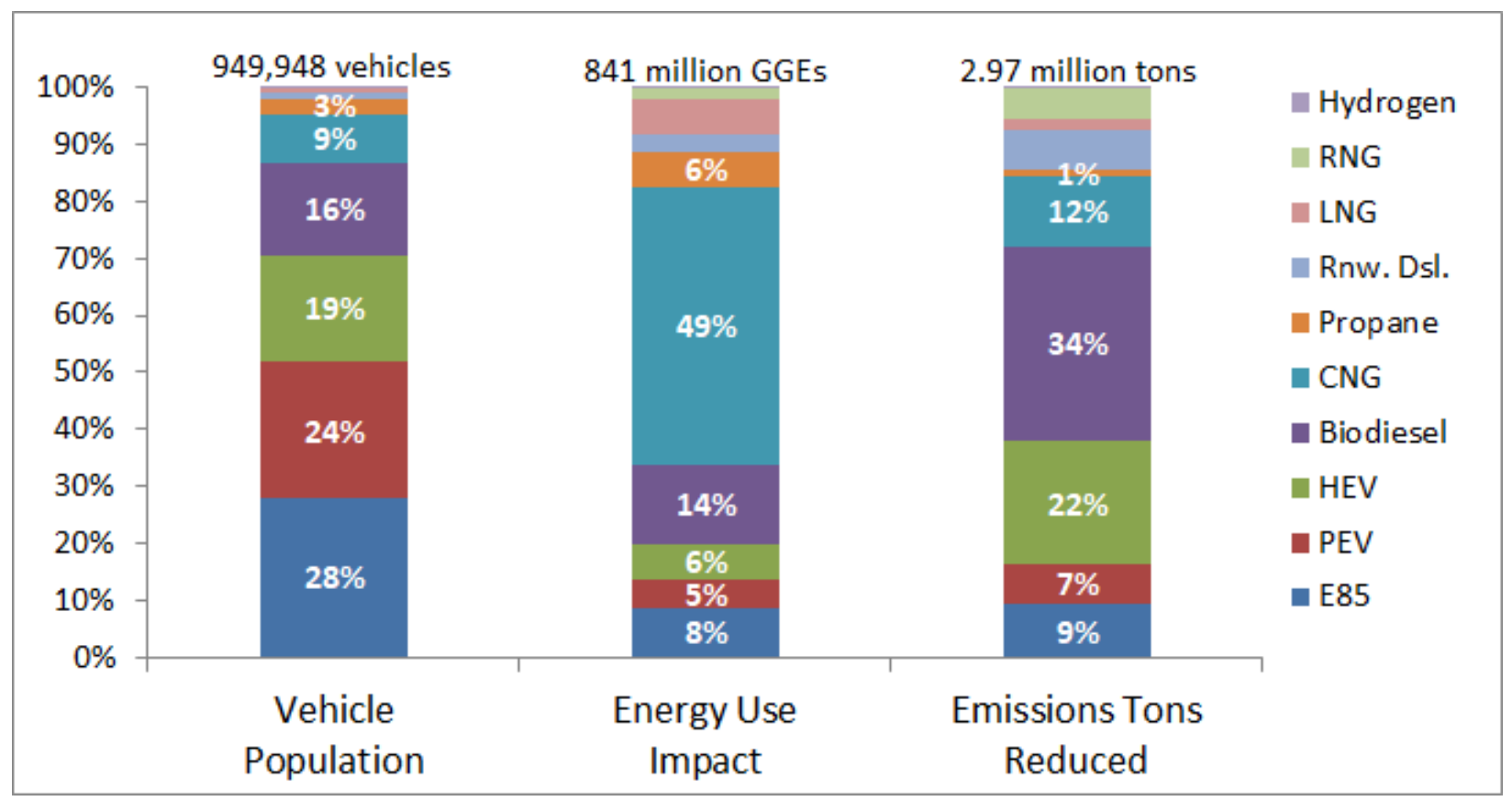

Figure 1. 2018 percentage of AFVs, EUI, and emissions reductions by fuel type

The average EUI per vehicle, shown in Table 3, reveals some interesting trends. For a given vehicle, this number is influenced by five factors:

1. Dedicated AFVs (those that can only operate on alternative fuel) have a higher EUI than flex-fuel, dual-fuel, or bi-fuel vehicles that can switch between fuels. Simply stated, dedicated AFVs use alternative fuel $100 \%$ of the time, while those with interchangeable fuel systems may only use alternative fuel some of the time.

2. The number of miles per year that the AFV travels (higher mileage uses more alternative fuel).

3. The AFV's fuel consumption. Large vehicles that are doing more work tend to consume more fuel. Therefore, Table 3 shows light-duty vehicles (LDVs) and heavy-duty vehicles (HDVs) separated to increase fidelity.

4. The amount of conventional fuel contained in an alternative fuel blend (e.g., B20 still contains $80 \%$ conventional diesel, so only a portion of the B20 fuel consumed counts toward the alternative fuel usage).

5. The amount of conventional fuel used to produce or transport the alternative fuel. For example, the diesel used to grow the corn that is turned into ethanol is subtracted from the EUI. 
Table 3. Average Annual EUI per Vehicle in 2018

\begin{tabular}{|l|r|r|r|r|}
\hline Fuel & \multicolumn{1}{|c|}{$\begin{array}{c}\text { GGE per } \\
\text { HDV }\end{array}$} & $\begin{array}{c}\text { \# of } \\
\text { HDVs }\end{array}$ & $\begin{array}{c}\text { GGE per } \\
\text { LDV }\end{array}$ & $\begin{array}{c}\text { \# of } \\
\text { LDVs }\end{array}$ \\
\hline RNG & 10,384 & 1,514 & 2,230 & 163 \\
\hline LNG & 10,136 & 5,100 & NA & 0 \\
\hline CNG & 6,911 & 54,574 & 1,216 & 27,692 \\
\hline Hydrogen & 5,900 & 306 & 504 & 96 \\
\hline PEV & 2,821 & 6,800 & 117 & 221,054 \\
\hline HEV & 2,749 & 8,770 & 164 & 169,963 \\
\hline Renewable Diesel. & 2,670 & 8,138 & 872 & 3,036 \\
\hline Propane & 2,652 & 14,977 & 1,216 & 10,418 \\
\hline Biodiesel & 1,075 & 98,460 & 188 & 54,920 \\
\hline E85 & 187 & 14,977 & 274 & 248,990 \\
\hline
\end{tabular}

Alternative fuels and AFVs were responsible for more GHG emissions reductions than any other coalition-reported activity. These reductions were calculated by subtracting the life-cycle GHG emissions resulting from the use of an alternative fuel in a vehicle from the life-cycle GHG emissions resulting from the use of gasoline or diesel fuel in an equivalent vehicle. For these calculations, gasoline is considered the baseline fuel for all LDVs, except in the case of biodiesel, for which conventional diesel fuel is used as the baseline fuel. Gasoline is considered the baseline fuel for HDVs using E85, CNG, liquefied natural gas (LNG), and propane because these vehicles are equipped with spark-ignition (gasoline-like) engines. For all other alternative fuel HDVs, we used conventional diesel fuel as the baseline.

As shown in Figure 1, the emissions reductions are not necessarily proportional to the alternative fuel used, because the various alternative fuels emit different levels of life-cycle emissions. RNG is a prime example of a fuel that has extremely low life-cycle emissions because it has the net effect of reducing methane (a GHG) emissions from landfills, wastewater

The average EUI of an HDV in the Technology Integration Program is more than 12 times as much as an LDV. treatment facilities, and farms. It is also worth noting that VMT reduction, HEVs, IR, and fuel economy improvement projects have a disproportionately high emissions reduction compared to their EUI because these conservation measures "eliminate" $100 \%$ of the emissions that would have resulted from the fuel they save. AFVs generally demonstrate a net "reduction" in emissions compared to vehicles that use conventional fuels.

High Impact Fleets and Vehicle Segments - Although HDVs represented only $22 \%$ of the reported AFVs, these HDVs are responsible for $78 \%$ of the alternative fuel use. The average HDV that operates on alternative fuels impacts 12.5 times as much fuel use as the average LDV. Likewise, the overwhelming majority of RNG, hydrogen, $\mathrm{CNG}$, biodiesel, and renewable diesel, is used by HDVs $(98 \%, 97 \%, 92 \%, 91 \%$, and $89 \%$, respectively). The use of LNG is confined exclusively to HDVs, and HDVs accounted for $76 \%$ of all propane use. Contributions from PEVs were more evenly split between LDVs and HDVs (57\% and 43\%, respectively). The only technology whose contributions were dominated by LDVs was E85 (with only $2 \%$ from HDVs). For HEVs, 55\% of the EUI impact was from LDVs. 


\section{Fuel Economy}

Coalitions completed a range of fuel economy projects aimed at using energy more efficiently. Non-HEV coalition-reported fuel economy projects accounted for a total savings of nearly 54 MGGE, making it the fastest-growing technology category. Figure 2 includes the range of fuel economy technologies advanced by coalitions. There were over 120,000 vehicles in the nonHEV fuel economy technology category, equating to an average annual EUI of 447 GGE per vehicle. Figure 2 shows that fuel economy improvement projects had the largest improvements when the vehicles were replaced with more efficient vehicles or hydraulic hybrid vehicles, but large fuel economy improvements can be made with less drastic changes, such as low-rolling resistance tires, trailer aerodynamic packages, and automatic tire inflation systems.

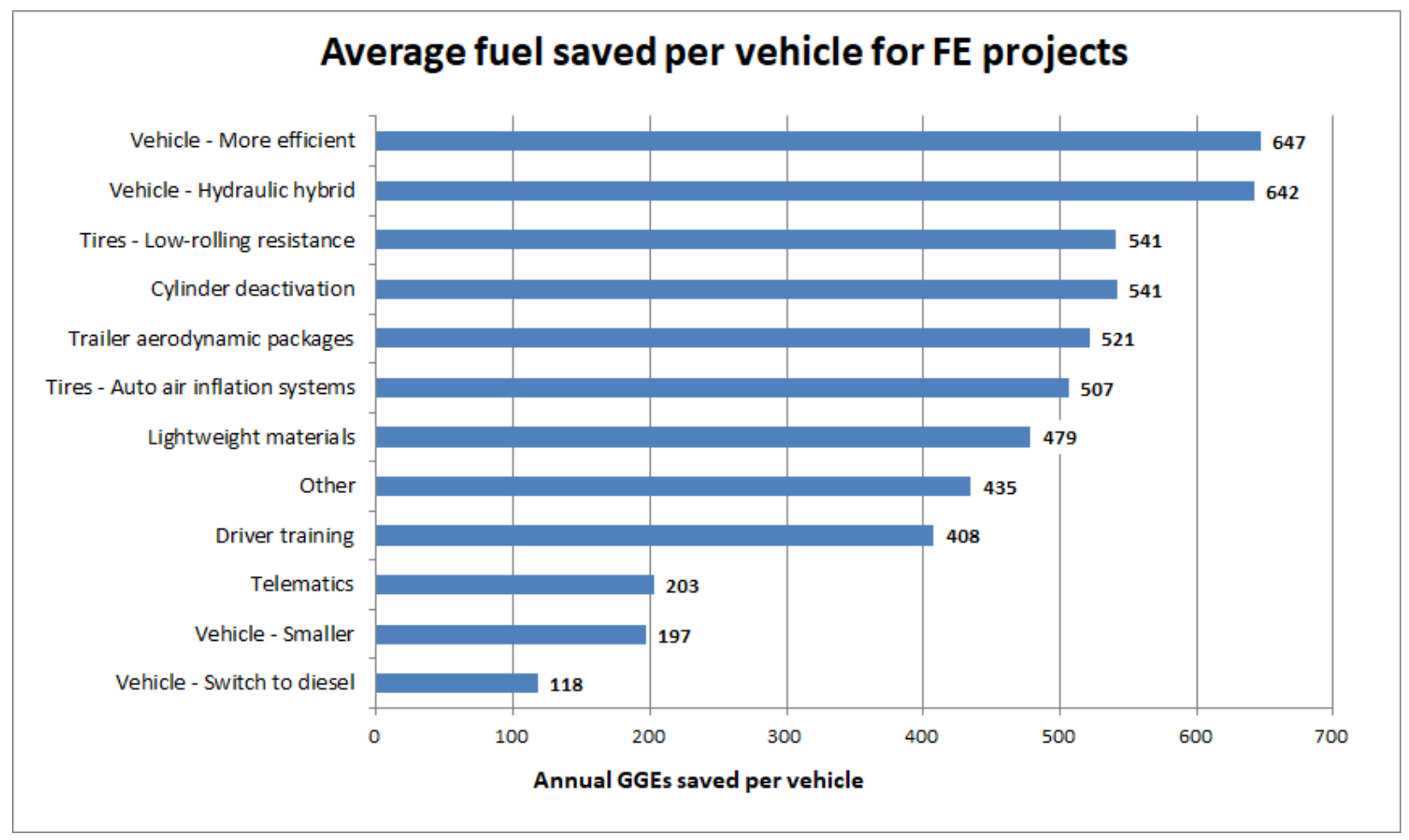

Figure 2. Average energy saved per vehicle for 2018 Clean Cities coalition fuel economy projects 


\section{Vehicle Miles Traveled Reduction}

VMT-reduction projects save fuel and therefore money, while simultaneously curbing emissions. These types of projects include strategies such as carpooling, biking, teleworking, and public transportation. Fifty-nine of the 81 reporting coalitions $(73 \%)$ reported at least one VMTreduction project in 2018, with a total of 361 projects reported. VMT projects are generally outside the scope of advanced vehicle, fuel, and systems research addressed by VTO. Since the primary purpose of this report is to analyze and document the impact of Clean Cities coalition efforts related to VTO technologies, the contribution of VMT projects is limited to $10 \%$ of any given coalition's total energy savings. This cap affected 17 coalitions; however, even with this limit in place, coalitions saved 31.3 MGGE of fuel with VMT activities. The project types, numbers, and sizes of the VMT projects are shown in Table 4.

Table 4. VMT Reduction Project Types, Number, and Energy Savings in 2018

\begin{tabular}{|c|c|c|c|c|}
\hline Project Type & $\begin{array}{c}\text { Number of } \\
\text { Projects }\end{array}$ & $\begin{array}{l}\text { Increase in } \\
\text { \# of Projects } \\
\text { over } 2017\end{array}$ & $\begin{array}{c}\text { GGE Saved } \\
\text { per } \\
\text { Project }^{\mathrm{a}}\end{array}$ & $\begin{array}{l}\text { DOE-claimed GGE } \\
\text { Saved per } \\
\text { Project }\end{array}$ \\
\hline Carpooling & 68 & -7 & 64,572 & 43,166 \\
\hline Mass transit & 67 & -6 & 473,643 & 253,369 \\
\hline Route optimization & 62 & -7 & 41,988 & 40,856 \\
\hline $\begin{array}{l}\text { Nonmotorized locomotion } \\
\text { (e.g., bicycles) }\end{array}$ & 62 & 9 & 29,978 & 28,391 \\
\hline Other & 28 & -9 & 132,055 & 58,995 \\
\hline Telecommute & 24 & -3 & 10,786 & 9,480 \\
\hline Car sharing (e.g., Zipcar) & 20 & -2 & 19,794 & 19,282 \\
\hline Vanpooling & 17 & 0 & 495,143 & 279,169 \\
\hline Compressed work week & 13 & -2 & 7,933 & 7,842 \\
\hline Total & 361 & -27 & $148,088^{a}$ & 86,751 \\
\hline
\end{tabular}

${ }^{a}$ GGE per project calculated before the $10 \%$ limit of coalition overall energy savings was implemented.

\section{Idle Reduction}

The estimated energy savings in 2018 for IR technologies and policies was 42.9 MGGEs. The number of IR projects increased $5 \%$ in 2018 , yet the quantity of energy that these projects saved decreased 3\%. As shown in Figure 3, at 14

Savings from onboard batteries more than doubled from 2017 to 2018. MGGE, auxiliary power units were responsible for the greatest percentage (33\%) of energy savings. Automatic engine shutoff, at 7.4 MGGE; IR policies, at 4.6 MGGE; direct-fire heaters, at 4.3 MGGE; and the "other" category, at 3.8 MGGE; followed with significant percentages $(17 \%, 11 \%, 10 \%$, and $9 \%$ respectively). Truck-stop electrification, at $2.8 \mathrm{MGGE}$; on-board batteries, also at 2.8 MGGE; and driver training, at 2.6 MGGE had similar impacts (6\% each). The remaining methods combined to represent $2 \%$ of the total savings. 


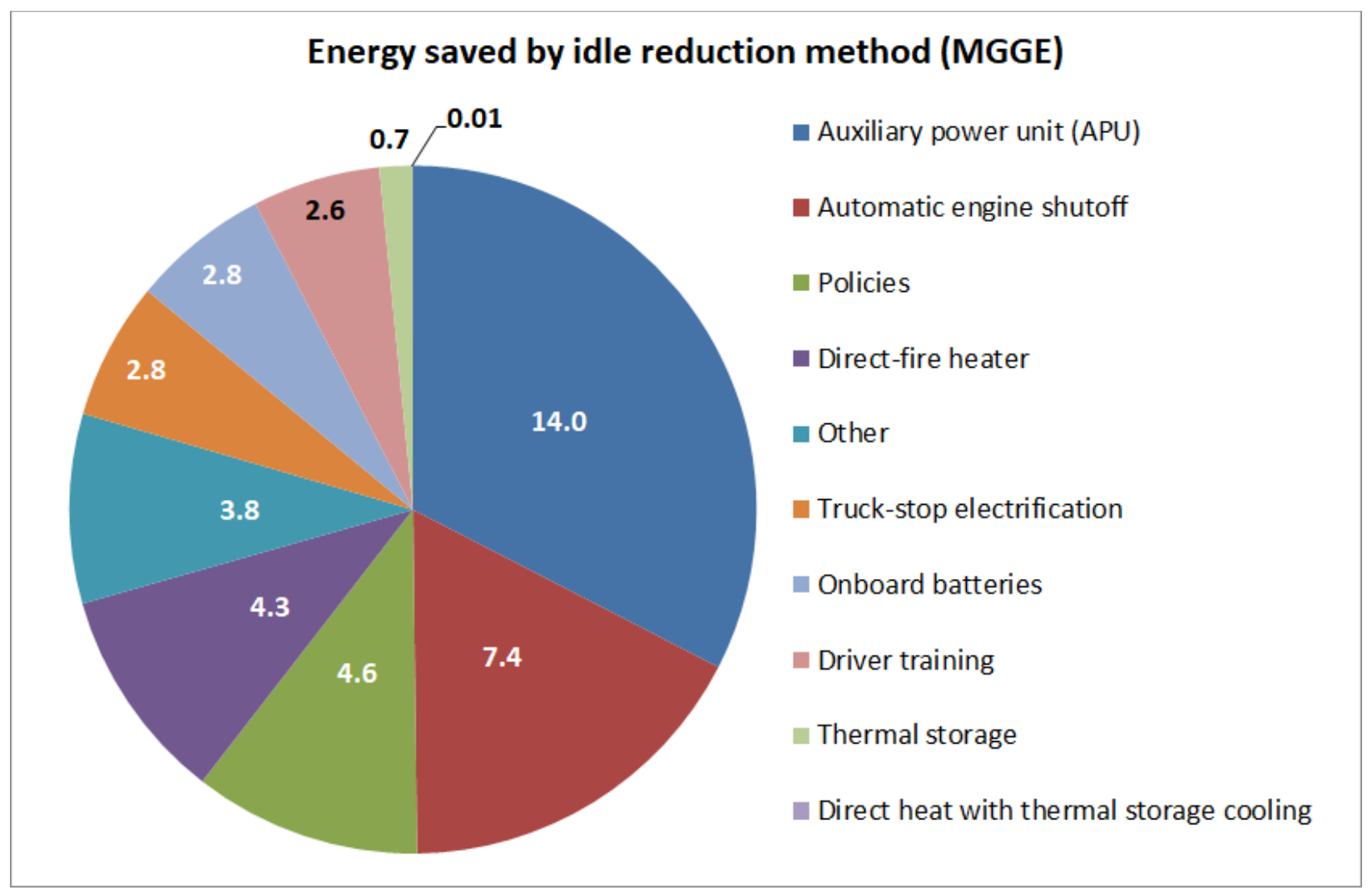

Figure 3. Energy savings measured in MGGE from IR projects, 2018

\section{Off-Road Vehicles}

Vehicles used in off-road applications contributed to the overall accomplishments reported by coalitions. Many of these projects were born out of synergy with on-road projects, using many of the same alternative fuels, technologies, and strategies. Table 5 shows the number of off-road vehicles (or pieces of equipment) reported by coalitions in 2018. These categories are self-descriptive, except

Coalition impact extends beyond the road. Off-road project EUI was nearly 18 MGGE in 2018. for three. "Construction equipment" includes cranes, earth movers, and similar equipment. The "recreation equipment" application includes jet skis, snowmobiles, and all-terrain vehicles. The "other" category includes vehicle speed limitations and changes to hydraulic pumps. 
Table 5. Number of Off-Road Vehicles or Equipment and EUI in 2018

\begin{tabular}{|l|r|r|r|}
\hline \multicolumn{1}{|c|}{ Application } & $\begin{array}{c}\text { Number of } \\
\text { Vehicles }\end{array}$ & $\begin{array}{c}\text { Energy Use } \\
\text { Impact } \\
\text { (GGE) }\end{array}$ & $\begin{array}{c}\text { GGE } \\
\text { saved per } \\
\text { Vehicle }\end{array}$ \\
\hline Other & 6,537 & $4,844,736$ & 741 \\
\hline Construction equipment & 5,589 & $1,484,837$ & 266 \\
\hline Forklifts & 4,337 & $2,616,666$ & 603 \\
\hline Mining equipment & 1,665 & $1,763,756$ & 1,059 \\
\hline Landscaping and lawn equipment & 1,348 & 238,733 & 177 \\
\hline Recreational equipment & 419 & 113,254 & 270 \\
\hline Ships & 144 & $4,882,080$ & 33,903 \\
\hline Farm equipment & 92 & 171,469 & 1,864 \\
\hline Street sweeper & 77 & 165,944 & 2,155 \\
\hline Railroads & 44 & $1,513,969$ & 34,408 \\
\hline Planes & 3 & 3,243 & 1,081 \\
\hline \hline Total & 20,255 & $17,798,687$ & 76,528 \\
\hline
\end{tabular}

Overall EUI contributions from off-road vehicles totaled 17.8 MGGE. Vehicles using biodiesel accounted for $52 \%$ of the AFVs included in this category. Vehicles using other fuels in off-road applications included propane (21\% of the total) and EVs $(17 \%)$. The other fuels and technologies together accounted for $10 \%$ of the total vehicles. Biodiesel use was focused in mining equipment, ships, and construction equipment applications. EVs were primarily used in the other equipment, forklifts, and recreational equipment. Propane vehicles were primarily reported as forklifts, construction equipment, and landscaping equipment. Applications varied widely in number of GGE saved per vehicle, as shown in Table 5.

\section{National Clean Fleets Partnership Contributions}

In April 2011, DOE began partnering with national fleets that operate in more expansive geographic areas than any one coalition covers. The NCFP currently has 28 partners, who lead by example and are pace-setters for local stakeholder fleets. Ten of them reported their fuel use data directly to NREL. NREL then allocated NCFP data to 74 individual coalitions based on fleet garage locations, refueling locations, and partner estimates. The coordinators then verified that they did assist the NCFP fleets operating in their regions and claimed full, partial,

Ten national fleets have partnered with Clean Cities coalitions, sharing data reflecting efforts that span geographic areas larger than that of any single coalition. or no credit for the partner's alternative fuel use that was attributed to them. Table 6 shows the contributions to total Clean Cities EUI that were attributed to national partners. 
Table 6. Vehicles, EUI, and Emissions Reduction from National Partners

\begin{tabular}{|l|r|r|r|}
\hline \multicolumn{1}{|c|}{ Fuel } & Vehicles & \multicolumn{1}{c|}{$\begin{array}{c}\text { Energy Use } \\
\text { Impact } \\
\text { (GGE) }\end{array}$} & $\begin{array}{c}\text { GHG } \\
\text { Reduced } \\
\text { (tons) }\end{array}$ \\
\hline CNG & 16,583 & $136,350,664$ & 114,892 \\
\hline LNG & 1,908 & $39,635,857$ & 39,755 \\
\hline Fuel Economy & 44,482 & $21,765,773$ & 269,882 \\
\hline Propane & 4,325 & $13,705,426$ & 5,373 \\
\hline PEV & 6,308 & $11,065,319$ & 44,711 \\
\hline Biodiesel & 2,231 & $8,722,044$ & 76,398 \\
\hline HEV & 1,722 & $2,690,971$ & 33,147 \\
\hline Renewable Diesel & 197 & $2,426,350$ & 21,252 \\
\hline RNG & 51 & $1,360,139$ & 13,283 \\
\hline Idle Reduction & 2,499 & 177,269 & 2,198 \\
\hline Hydrogen & 16 & 107,294 & 429 \\
\hline Off-Road & 361 & 34,902 & 47 \\
\hline VMT & 50 & 14,605 & 181 \\
\hline E85 & 97 & 9,687 & 38 \\
\hline \hline Total & 80,683 & $238,042,008$ & 621,368 \\
\hline
\end{tabular}

\section{Estimated Contributions from Outreach Activities}

This category measures impact from behavior changes such as vehicle purchases, fuel choice, driving habits, vehicle maintenance, and transportation patterns that were influenced by coalition outreach activities. Calculating these contributions involves a fair degree of uncertainty, but it is nevertheless important to quantify the impacts of educational and outreach activities as much as possible. Not doing so would imply that these activities had no impact, which is inaccurate. This section outlines our approach and provides the results.

\section{Methods Used to Estimate Energy Use Impact from Outreach Activities}

To estimate net alternative fuel use and emission reductions from outreach events, NREL and Oak Ridge National Laboratory developed the Behavioral Impact Model (BIM) and added related functionality to the Clean Cities coalition annual reporting tool to make it compatible with the BIM.

Clean Cities coordinators reported the type of outreach event, the number of people reached by each event, the technologies presented, and the percent that should be attributed to the coalition. To determine the number of people reached by a given event, the total number of people attending the event was multiplied by the percent of the event that the coalition claimed credit for. When multiple technologies were presented at a given event, the annual report assumed the number of people reached
Impacts from coalition outreach events are estimated using standard analytical methods derived from advertising and marketing industries. to be divided evenly among the technologies. These data are then entered into the BIM as "persons reached by the coalition about a given technology." 
The BIM multiplies this persons-reached number by the probability a person will take an action as a result of the outreach (defined as purchasing an AFV or more efficient vehicle, or as changing driving or fueling behavior). This probability is derived by comparing the outreach event and technology to comparable marketing media and products. Ten of these media-product combinations have a "customer conversion rate" that is recorded by various marketing firms, as shown in Table 7. The customer conversion rate is the ratio of purchases made (desired action) divided by the total number of people contacted through the outreach activity. The code column in Table 7 is provided for trackability through the calculation process, as continued to Table 9.

Table 7. Benchmark Customer Conversion Rates and Their Sources

\begin{tabular}{|c|c|c|}
\hline Code & Benchmark Conversion Rate & Reference \\
\hline 1 & $\begin{array}{l}0.6 \% \text { for electronics (expensive, } \\
\text { complicated) websites }\end{array}$ & Fireclick.com, accessed June 16, 2011 \\
\hline 2 & $\begin{array}{l}1.3 \% \text { for environmentally related, } \\
\text { incremental cost purchase }\end{array}$ & $\begin{array}{l}\text { Bird, Lori. 2004. Utility Green Pricing Programs: } \\
\text { Design, Implementation, and Consumer Response }\end{array}$ \\
\hline 3 & $\begin{array}{l}2 \% \text { for common websites and website } \\
\text { ads }\end{array}$ & $\begin{array}{l}\text { Nielsen and Facebook, 2010. Advertising } \\
\text { Effectiveness: Understanding the Value of a Social } \\
\text { Media Impression. And Fireclick.com, accessed } \\
\text { June 16, } 2011\end{array}$ \\
\hline 4 & $2.5 \%$ for industry-specific mail & Direct Marketing Association. 2011 \\
\hline 5 & $3.2 \%$ for email & Fireclick.com, accessed June 16, 2011 \\
\hline 6 & $\begin{array}{l}7 \% \text { for affiliates and } 8 \% \text { for "social ads" } \\
\text { that are endorsed by peers }\end{array}$ & $\begin{array}{l}\text { Fireclick.com, accessed June } 16,2011 \text {. Nielsen } \\
\text { and Facebook, 2010. Advertising Effectiveness: } \\
\text { Understanding the Value of a Social Media } \\
\text { Impression }\end{array}$ \\
\hline 7 & $0.6 \%$ AdMeasure product: LDVs & $\begin{array}{l}\text { GfK Mediamark Research \& Intelligence, LLC. } \\
2011\end{array}$ \\
\hline 8 & 5.5\% AdMeasure product: Gasoline & $\begin{array}{l}\text { GfK Mediamark Research \& Intelligence, LLC. } \\
2011\end{array}$ \\
\hline 9 & $\begin{array}{l}17 \% \text { AdMeasure smoking cessation } \\
\text { "actions taken" }\end{array}$ & $\begin{array}{l}\text { GfK Mediamark Research \& Intelligence, LLC. } \\
2011\end{array}$ \\
\hline 10 & $2 \%$ for direct mail to current customers & $\begin{array}{l}\text { Eisenberg, B. "The Average Conversion Rate: Is it } \\
\text { a Myth?" ClickZ. February 1, } 2008\end{array}$ \\
\hline
\end{tabular}

For activity-type/audience-action combinations that were not directly addressed by research, NREL adjusted the customer conversion rates based on the Ostrow Model of Effective Frequency, Krugman's Three Exposure Theory, and the authors' assumptions. Table 8 lists a set of relationships that increase or decrease the impact of advertisements. 
Table 8. Relationships for Media Effectiveness and Their Sources

\begin{tabular}{|l|l|l|}
\hline Code & \multicolumn{1}{|c|}{ Relationships } & \multicolumn{1}{c|}{ Source } \\
\hline A & Degree of media interactivity increases impact & Ostrow Model of Effective Frequency \\
\hline B & Brand recognition increases impact & Ostrow Model of Effective Frequency \\
\hline C & Long purchase cycle increases impact & Ostrow Model of Effective Frequency \\
\hline D & Less frequent usage of item increases impact & Ostrow Model of Effective Frequency \\
\hline E & Affordability of item increases impact & Ostrow Model of Effective Frequency \\
\hline F & Simple message increases impact & Ostrow Model of Effective Frequency \\
\hline G & Media clarity (not cluttered) increases impact & Ostrow Model of Effective Frequency \\
\hline H & Message in relevant environment increases impact & Ostrow Model of Effective Frequency \\
\hline I & Audience attentiveness increases impact & Ostrow Model of Effective Frequency \\
\hline J & More steps in processing the media increases impact & Krugman's Three Exposure Theory \\
\hline K & Availability of item increases impact & Author's Assumption \\
\hline L & Length of vigilance required decreases impact & Author's Assumption \\
\hline
\end{tabular}

We adjusted the benchmark conversion rates shown in Table 7 by the relationships for media effectiveness shown in Table 8. The direct application of these rates and relationships is shown in Table 9, where the number relates to the code in Table 7 and the letters relate to the code in Table 8. The final customer conversion rates used are displayed in Table 10.

Table 9. Combination of Benchmarks and Relationships

\begin{tabular}{|c|c|c|c|c|c|c|c|c|c|}
\hline Activity Type & $\begin{array}{l}3 \\
2 \\
2 \\
0 \\
0 \\
0 \\
\frac{0}{0} \\
\frac{1}{0} \\
\frac{0}{3} \\
0\end{array}$ & 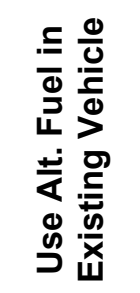 & 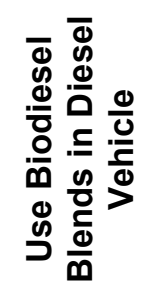 & 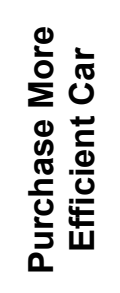 & 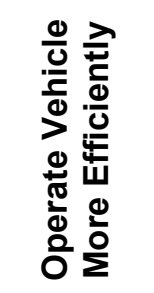 & 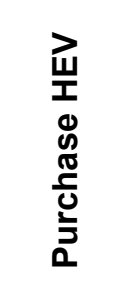 & 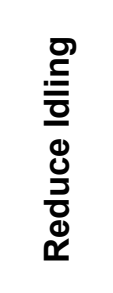 & 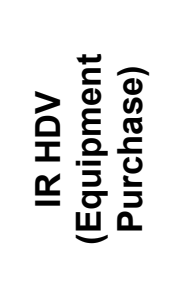 & 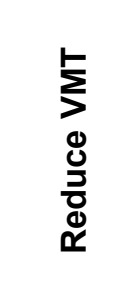 \\
\hline $\begin{array}{l}\text { Advancing the } \\
\text { Choice }\end{array}$ & $\begin{array}{l}6+\mathrm{H}+\mathrm{I} \\
+\mathrm{J}-\mathrm{E}\end{array}$ & $\underset{J}{6+\mathrm{H}+\mathrm{I}+}$ & $6+\mathrm{H}+\mathrm{I}+\mathrm{J}$ & $\begin{array}{c}6+\mathrm{H}+\mathrm{I} \\
+\mathrm{J}\end{array}$ & $6+\mathrm{H}+\mathrm{I}+\mathrm{J}$ & $\begin{array}{l}6+\mathrm{H}+\mathrm{I} \\
+\mathrm{J}-\mathrm{E}\end{array}$ & $\begin{array}{c}6+\mathrm{H}+\mathrm{I} \\
+\mathrm{J}\end{array}$ & $\begin{array}{c}6+\mathrm{H}+\mathrm{I}+\mathrm{J}- \\
\mathrm{E}\end{array}$ & $6+\mathrm{H}+\mathrm{I}+\mathrm{J}$ \\
\hline Advertisement & $7-\mathrm{K}$ & 8-K-L & 8-K-L & $7+E$ & 9-G-L & $7-K$ & 9-L & $7+E$ & 9-L \\
\hline Conference & $\underset{E}{6+\mathrm{H}+\mathrm{J}-}$ & $6+\mathrm{H}+\mathrm{J}$ & $6+\mathrm{H}+\mathrm{J}$ & $6+\mathrm{H}+\mathrm{J}$ & $6+\mathrm{H}+\mathrm{J}$ & $\begin{array}{c}6+\mathrm{H}+\mathrm{J} \\
-\mathrm{E}\end{array}$ & $\underset{\mathrm{J}}{6+\mathrm{H}+}$ & $6+\mathrm{H}+\mathrm{J}-\mathrm{E}$ & $6+\mathrm{H}+\mathrm{J}$ \\
\hline $\begin{array}{l}\text { Literature } \\
\text { Distribution }\end{array}$ & $\begin{array}{c}4+B+H \\
-E\end{array}$ & $4+B+H$ & $4+B+H$ & $4+B+H$ & $4+B+H$ & $\begin{array}{c}4+B+H \\
-E\end{array}$ & $\underset{H}{4+B+}$ & $4+\mathrm{B}+\mathrm{H}-\mathrm{E}$ & $4+B+H$ \\
\hline Media Event & $\begin{array}{c}\text { 7-E-G- } \\
\text { H-K }\end{array}$ & 8-G-H-K & 8-G-H-K & $\begin{array}{l}\text { 7-G- } \\
H+E-K\end{array}$ & 9-G-H-K & $\begin{array}{l}\text { 7-E-G- } \\
H+B-K\end{array}$ & $\begin{array}{l}\text { 9-G- } \\
\mathrm{H}-\mathrm{K}\end{array}$ & 7-E-G-H-K & 9-G-H-K \\
\hline Meeting & $\begin{array}{l}6+A+B \\
+I-E\end{array}$ & $\begin{array}{c}6+A+B+ \\
1\end{array}$ & $6+A+B+1$ & $\begin{array}{c}6+A+B \\
+1\end{array}$ & $6+A+B+1$ & $\begin{array}{l}6+A+B \\
+I-E\end{array}$ & $\begin{array}{c}6+A+ \\
B+1\end{array}$ & $\begin{array}{c}6+A+B+1- \\
E\end{array}$ & $\begin{array}{l}6+A+B+ \\
1\end{array}$ \\
\hline Website & $1+B+J$ & $3+B+J$ & $3+B+J$ & $3+B+J$ & $3+B+J$ & $1+B+J$ & $\underset{\mathrm{J}}{3+\mathrm{B}+}$ & $1+B+J$ & $3+B+J$ \\
\hline
\end{tabular}


Table 10. Customer Conversion Rates Used in the BIM

\begin{tabular}{|c|c|c|c|c|c|c|c|c|c|}
\hline Activity Type & 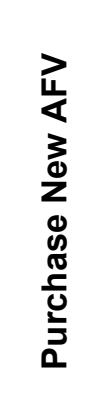 & 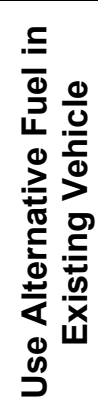 & 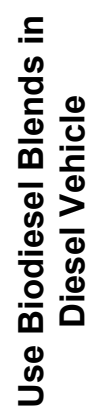 & 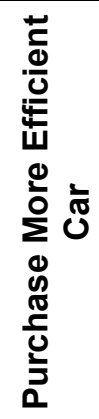 & 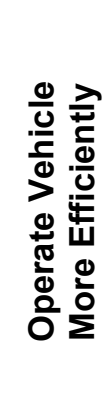 & 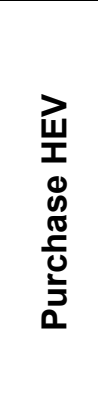 & 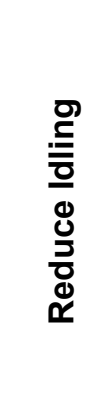 & 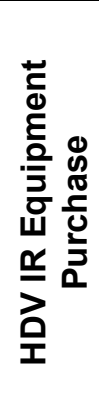 & 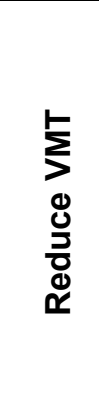 \\
\hline Advancing the Choice & $2.0 \%$ & $6.0 \%$ & $6.0 \%$ & $5.0 \%$ & $7.0 \%$ & $2.0 \%$ & $5.0 \%$ & $4.0 \%$ & $8.0 \%$ \\
\hline Advertisement & $0.6 \%$ & $5.5 \%$ & $5.5 \%$ & $2.0 \%$ & $10.0 \%$ & $2.0 \%$ & $10.0 \%$ & $3.0 \%$ & $4.0 \%$ \\
\hline Conference & $2.0 \%$ & $6.0 \%$ & $6.0 \%$ & $5.0 \%$ & $7.0 \%$ & $2.0 \%$ & $5.0 \%$ & $4.0 \%$ & $8.0 \%$ \\
\hline Literature Distribution & $2.0 \%$ & $3.0 \%$ & $3.0 \%$ & $2.5 \%$ & $3.0 \%$ & $2.5 \%$ & $3.0 \%$ & $2.5 \%$ & $5.0 \%$ \\
\hline Media Event & $0.6 \%$ & $2.5 \%$ & $3.0 \%$ & $1.2 \%$ & $3.0 \%$ & $1.2 \%$ & $4.0 \%$ & $2.0 \%$ & $2.0 \%$ \\
\hline Meeting-Other & $2.0 \%$ & $7.0 \%$ & $6.0 \%$ & $5.0 \%$ & $7.0 \%$ & $2.0 \%$ & $5.0 \%$ & $4.0 \%$ & $8.0 \%$ \\
\hline Website & $2.0 \%$ & $4.0 \%$ & $3.0 \%$ & $3.0 \%$ & $4.0 \%$ & $3.0 \%$ & $3.0 \%$ & $3.0 \%$ & $3.0 \%$ \\
\hline
\end{tabular}

The number of people reached multiplied by the appropriate customer conversion rate (from Table 10) results in the number of people assumed to take the intended action. After the conversion factors have been applied, the BIM is like the Clean Cities coalition annual reporting tool, as it converts the estimated number of vehicles purchased or number of people changing their driving habits into an EUI. We make downward adjustments of 30\%-40\% to the estimates to account for probable overlaps between audiences attending outreach events and entities reporting their own petroleum savings via a Clean Cities coalition. We apply the estimated petroleum savings only to the reporting year in question, even though many of the vehicle purchases and behavioral changes will likely last beyond that year.

\section{Estimated Outreach Accomplishments}

Coalitions' outreach, education, and training activities were classified into nine categories, as shown in Table 11. A total of 3,805 activity days were reported, which were estimated to have reached nearly 36 million people. This was heavily influenced by a media event effort by a single coalition that distributed a series of news releases that reached nearly 32 million people. Apart from this effort, outreach events reached over 4 million people overall and 1,059 people per event on average. Media events continued to be the activity that reached the most people. Conference participation reached the second most people at over 905,000, which was an increase of $29 \%$ since 2017. 
Table 11. Outreach, Education, and Training Activities

\begin{tabular}{|l|r|r|r|r|r|r|}
\hline Activity type & $\begin{array}{c}\text { Number } \\
\text { of } \\
\text { Activities }\end{array}$ & $\begin{array}{c}\text { Share of } \\
\text { Total } \\
\text { Activities }\end{array}$ & $\begin{array}{c}\text { Activities } \\
\text { Increase } \\
\text { Since } \\
\mathbf{2 0 1 7}\end{array}$ & $\begin{array}{c}\text { Persons } \\
\text { Reached }\end{array}$ & $\begin{array}{c}\text { Share of } \\
\text { Total } \\
\text { Persons } \\
\text { Reached }\end{array}$ & $\begin{array}{c}\text { Persons } \\
\text { Increase } \\
\text { Since } \\
\mathbf{2 0 1 7}\end{array}$ \\
\hline Meeting - Stakeholder & 945 & $24.8 \%$ & $42 \%$ & 27,013 & $0.1 \%$ & $46 \%$ \\
\hline Meeting - Other & 889 & $23.4 \%$ & $20 \%$ & 517,839 & $1.4 \%$ & $-27 \%$ \\
\hline $\begin{array}{l}\text { Conference } \\
\text { Participation }\end{array}$ & 695 & $18.3 \%$ & $10 \%$ & 905,747 & $2.5 \%$ & $29 \%$ \\
\hline $\begin{array}{l}\text { Workshop Held by } \\
\text { Coalition }\end{array}$ & 346 & $9.1 \%$ & $8 \%$ & 28,612 & $0.1 \%$ & $-31 \%$ \\
\hline Media Event & 285 & $7.5 \%$ & $24 \%$ & $33,184,536$ & $92.3 \%$ & $664 \%$ \\
\hline Literature Distribution & 258 & $6.8 \%$ & $-14 \%$ & 590,941 & $1.6 \%$ & $0 \%$ \\
\hline Social Media & 202 & $5.3 \%$ & $-3 \%$ & 133,356 & $0.4 \%$ & $53 \%$ \\
\hline Advertisement & 120 & $3.2 \%$ & $173 \%$ & 266,568 & $0.7 \%$ & $-84 \%$ \\
\hline Website & 65 & $1.7 \%$ & $183 \%$ & 281,420 & $0.8 \%$ & $-87 \%$ \\
\hline TOTAL & $\mathbf{3 , 8 0 5}$ & $\mathbf{1 0 0 . 0 \%}$ & $\mathbf{2 0 \%}$ & $\mathbf{3 5 , 9 3 6 , 0 3 2}$ & $\mathbf{1 0 0 . 0 \%}$ & $\mathbf{2 5 0 \%}$ \\
\hline
\end{tabular}

Figure 4 illustrates the types of audiences reached through the 3,805 outreach activities. Each activity could be aimed at multiple audiences; in fact, each activity targeted an average of 3.7 different audiences. Government fleets were the most-cited target audience, followed by the general public and private fleets. The other audience group, utility trucks, and mass transit groups were reached by similar percentages of activities. Delivery trucks, airports, and waste management were identified as audiences in less than $30 \%$ of the outreach activities. The composition of outreach activities was consistent with 2017.

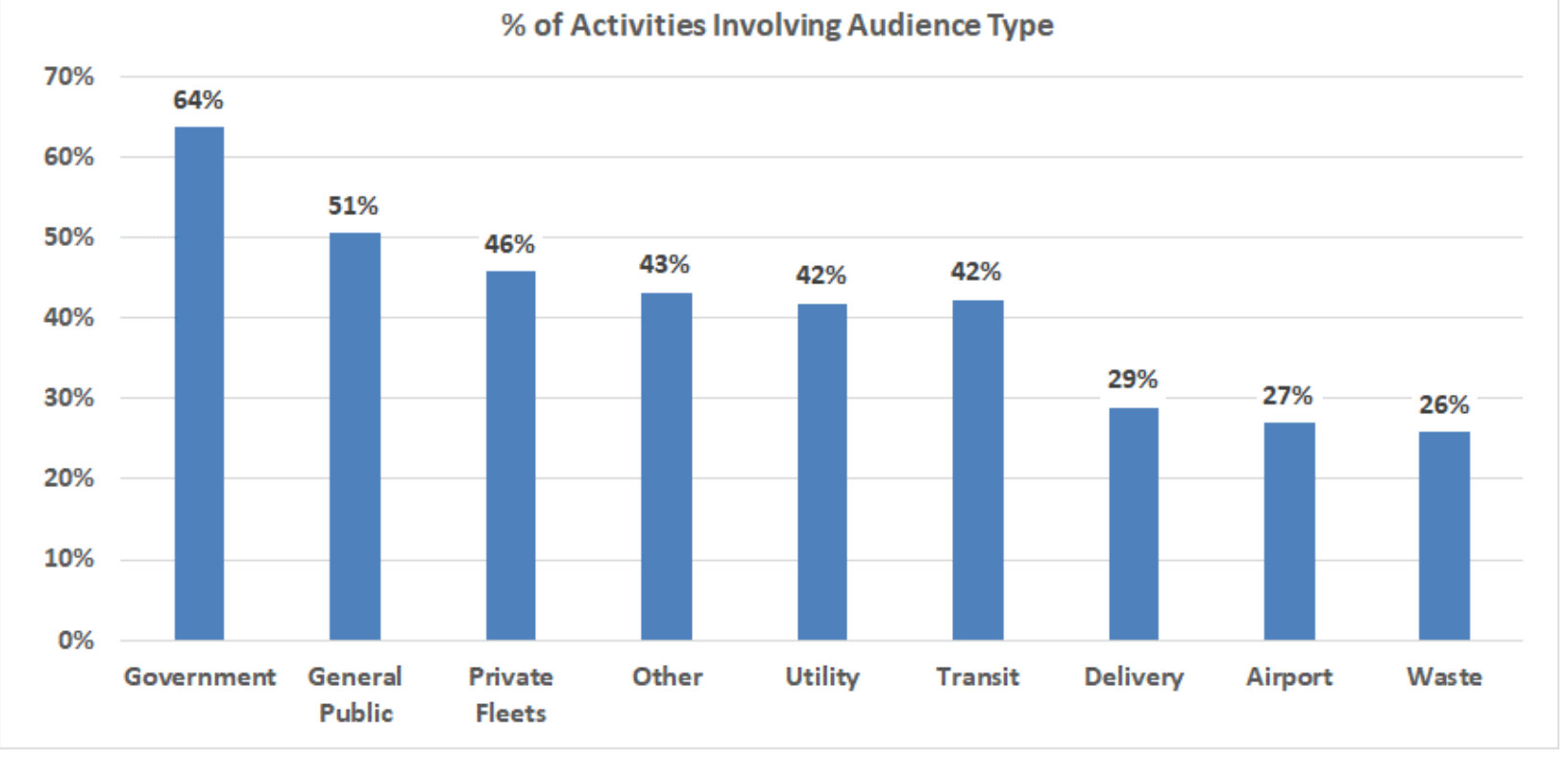

Figure 4. Percentage of outreach activities reaching each audience type

Coalitions' outreach events featured a relatively even mix of technologies, as illustrated in Figure 5, but EVs were covered more than any of the other technology types. Just as with audience types, any one activity could address more than one technology; each activity featured an average of 4.7 different technologies. 
$\%$ of Activities Involving Technology Type

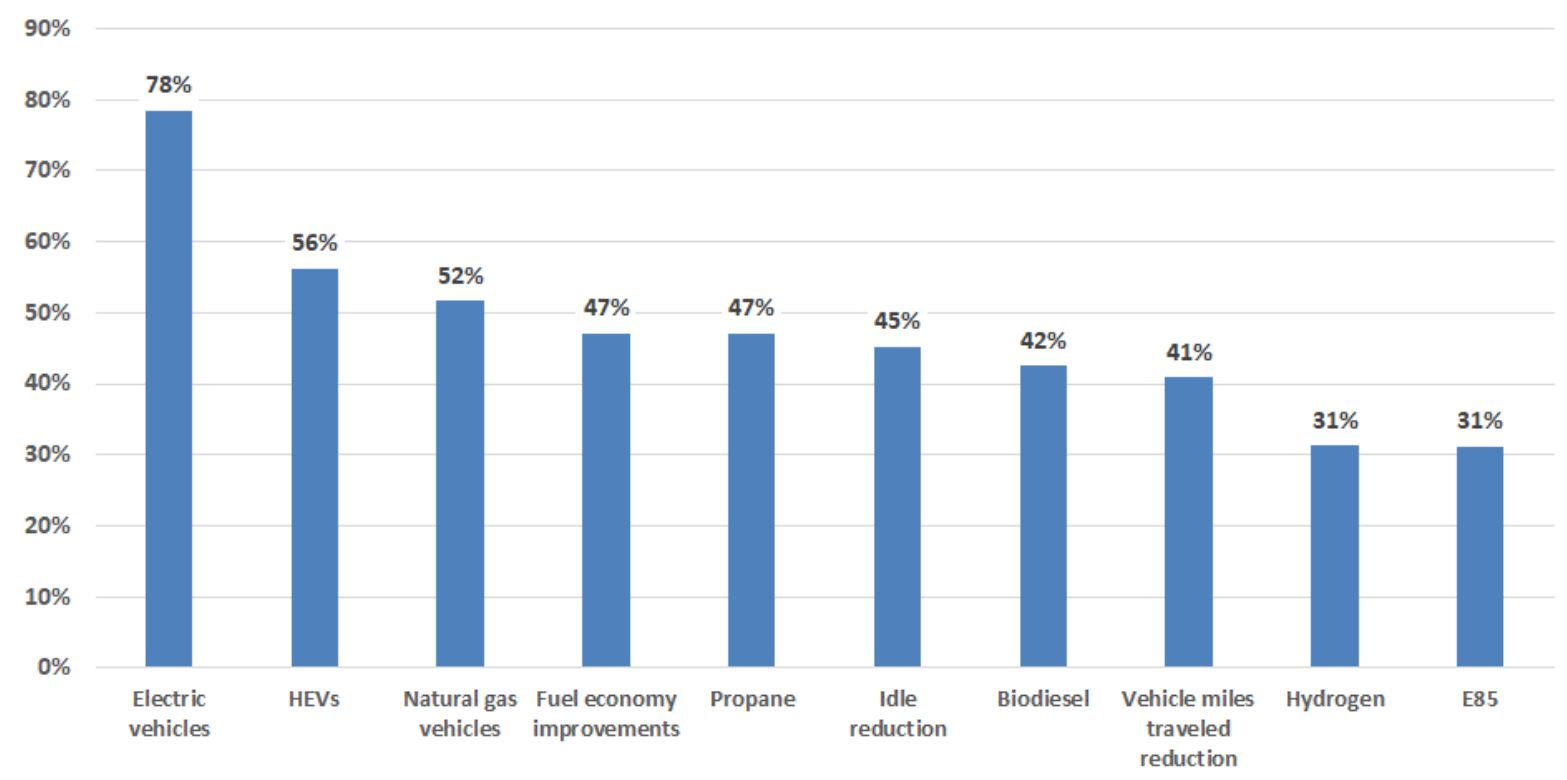

Figure 5. Percentage of outreach activities by technology type

Using the BIM, NREL estimates that Clean Cities coalition outreach events prompted and enabled actions that impacted over 69 MGGE of energy use in 2018, after accounting for a substantial overlap with reported impacts.

EVs were the most common topic of coalition outreach events.

\section{Cumulative Energy Use Impact}

Clean Cities coalitions have steadily increased their annual EUI as projects have been expanded and built upon each year. Figure 6 shows coalition annual EUI has reached new levels in recent years. During the first 10 years of tracking (1994-2003), coalitions increased the annual EUI by an average of 16 MGGE per year. In the last 10 years of tracking (2008-2018) coalitions have increased their annual EUI by an average of 77 MGGE per year. The 2018 reporting year showed the coalitions reaching an annual EUI of over a billion GGE for the first time. 


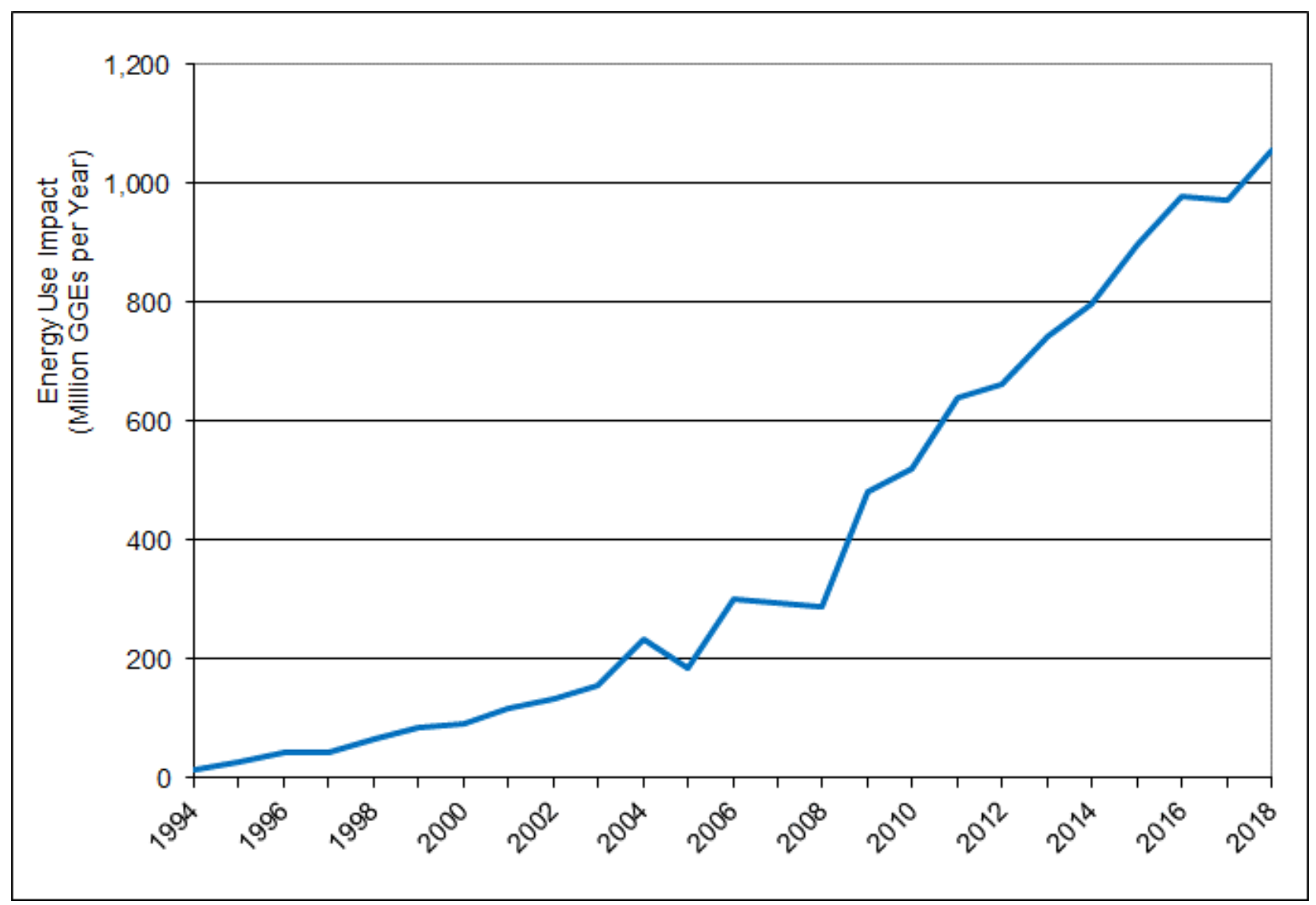

Figure 6. Increasing energy use impact (EUI) from coalitions

The impacts of Clean Cities coalition efforts have added up considerably over the years. The full extent of the program's effect can be seen when the annual EUIs shown in Figure 6 are aggregated to a cumulative EUI. This cumulative measure, shown in Figure 7, is now nearly 10 billion GGE. 


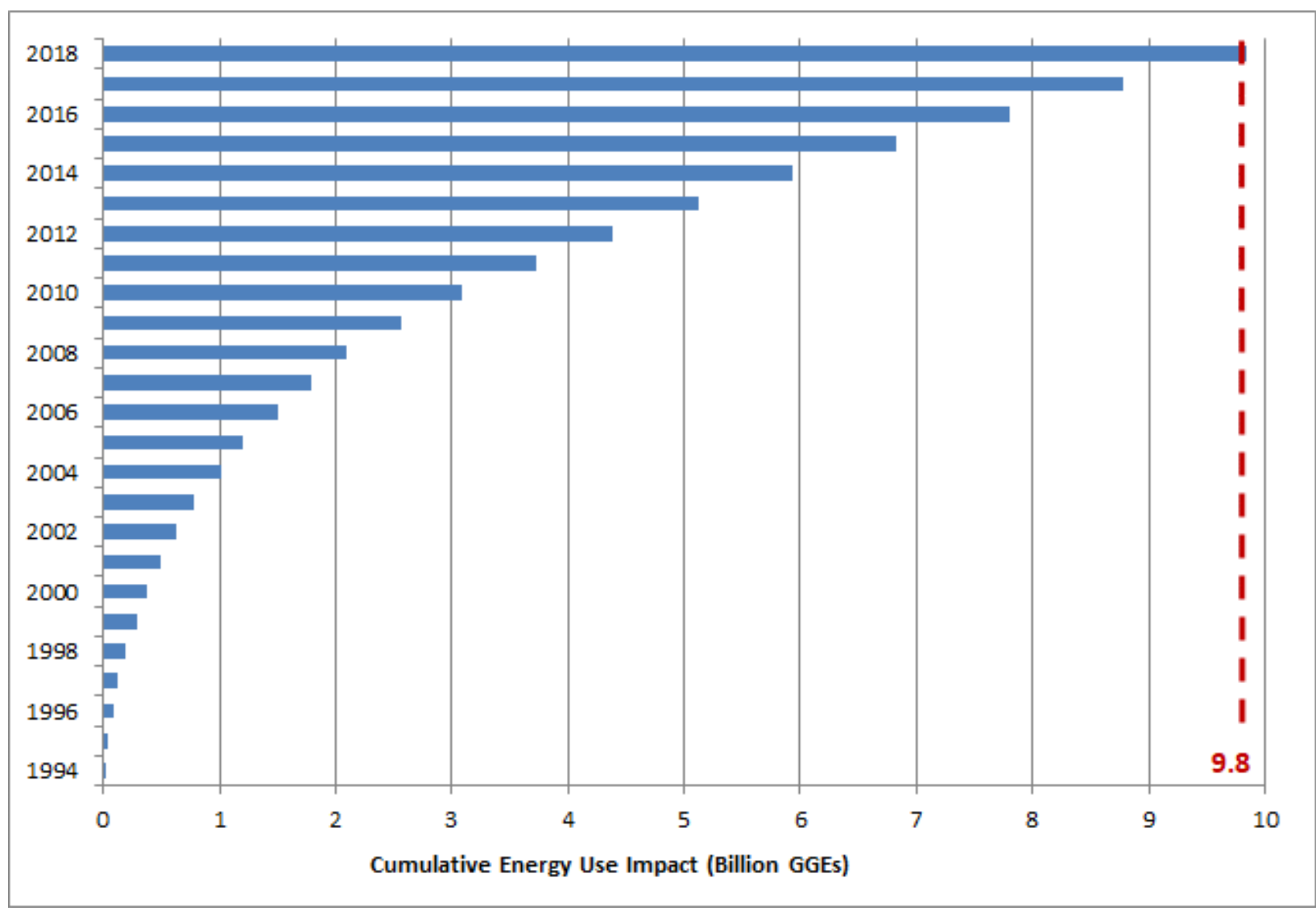

Figure 7. Cumulative accomplishments of all Clean Cities coalition activities

These efforts have also led to a cumulative emissions reduction of 52 million tons over the years, as shown in Figure 8. The relationship between the two has not always been consistent, since different technologies can be more effective at increasing EUI or reducing emissions (see Figure 2), and the Technology Integration portfolio continues to stay relevant by evolving over time. Furthermore, there was a shift in the emissions calculations in 2015 as the reporting tool was updated, along with the 2015 GREET model. Therefore, Figure 7 and Figure 8 do not reflect one another exactly. 


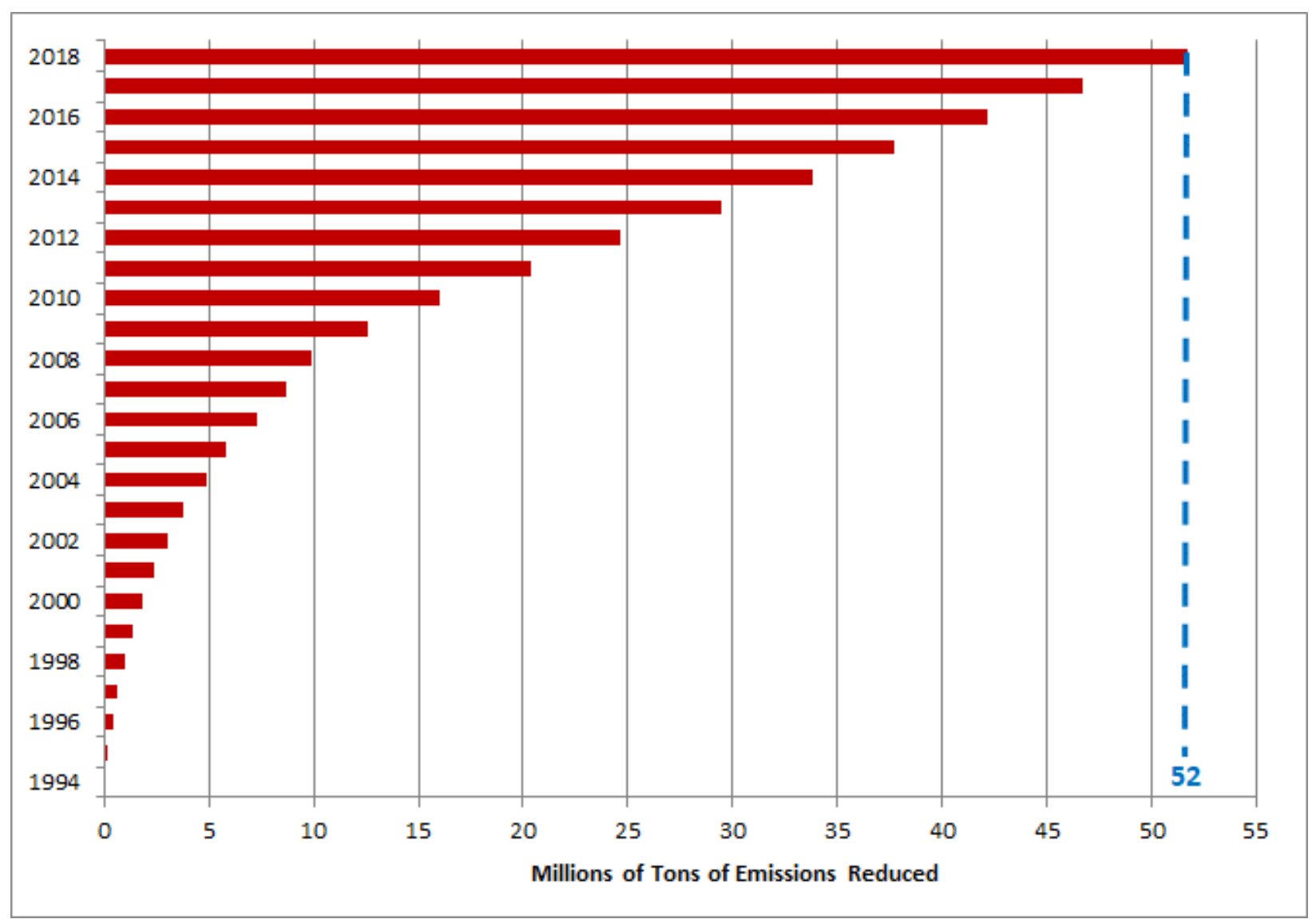

Figure 8. Cumulative emissions reductions from all Clean Cities coalition activities

\section{Alternative Fuel Vehicle Types and Applications}

The online reporting tool allows coordinators to categorize their AFVs into key vehicle types and fleet applications. Figure 9 shows that the largest portion (42\%) of AFVs were cars. Unknown LDVs, which are usually vehicles reported in conjunction with a Clean Cities coalitionsupported fueling station, were the second most reported vehicle type (24\%). Light trucks/vans/sport utility vehicles represented $10 \%$ of vehicles. Unknown HDVs, typically reported in conjunction with public biodiesel fueling stations, accounted for $8 \%$ of vehicles, while heavy duty trucks without trailers, or delivery trucks, accounted for $6 \%$. All remaining categories individually accounted for $3 \%$ or less of the vehicle population.

PEVs in the car segment were the most frequently reported fuel/vehicle combination at over 170,000. HEVs in the car segment followed at over 160,000. E85 capable vehicles were the largest portion (nearly 250,000 vehicles) of the typical light-duty passenger vehicles segments including the unknown light-duty segment, the car segment, the light trucks/vans/sport utility vehicles segment, and the patrol car segment. Together these E85 capable vehicles represented $26 \%$ of all vehicles. 


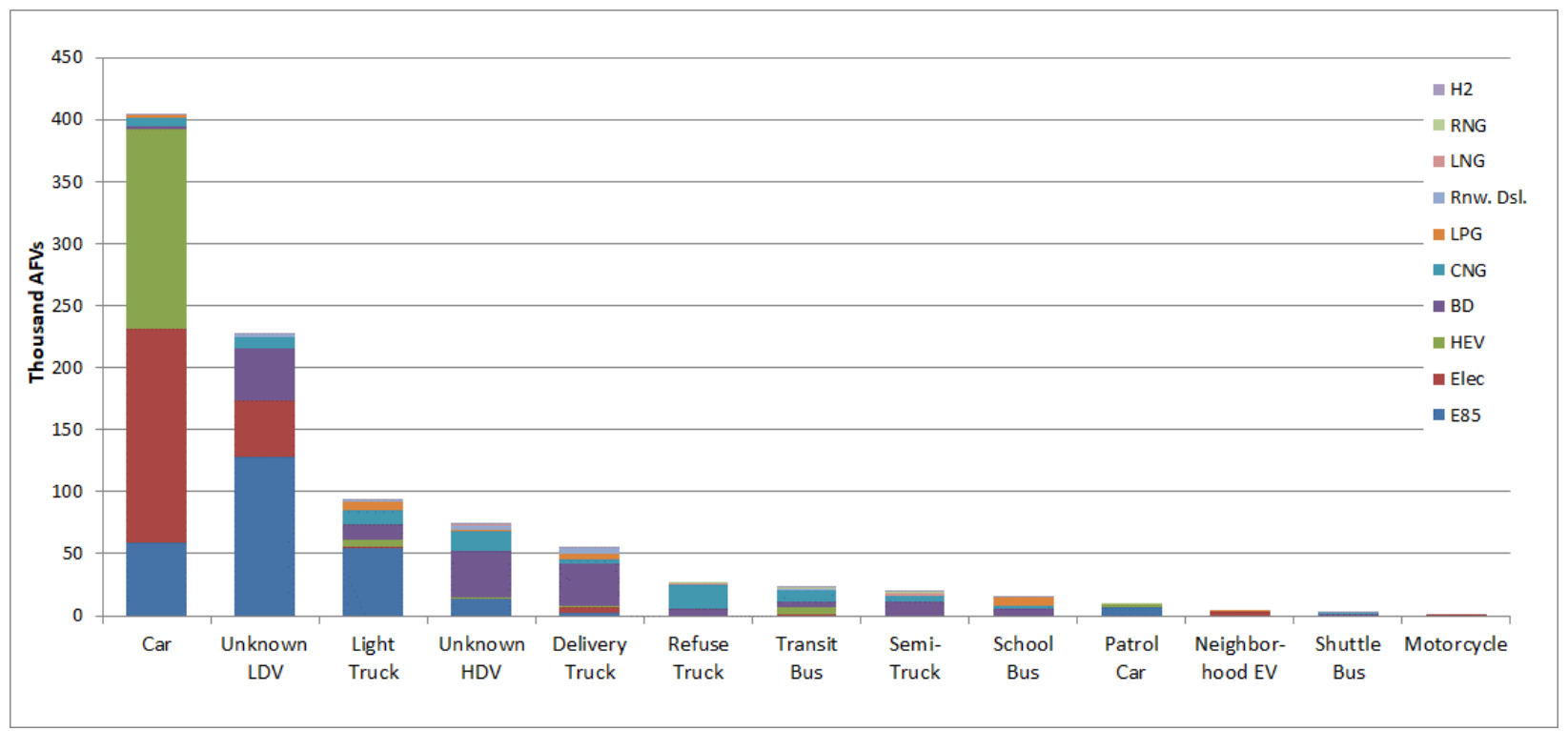

Figure 9. AFVs by vehicle and fuel type

*Neighborhood EVs are small EVs only allowed on low-speed roads.

In addition to reporting vehicle types, coordinators also provided information about vehicle ownership and vehicle end use applications. As shown in Figure 10, more than half of the reported vehicles (57\%) were owned by the general public or an unknown entity. Many of these vehicles were reported by fuel retailers to the coordinator, often back-calculated from fuel sales and an assumption for how much fuel the average car uses per year. The next largest ownership groups of AFVs were local government fleets, state government fleets, and corporate fleets, at $15 \%, 10 \%$, and $7 \%$ of the total vehicles, respectively.

State fleets, local fleets, utility vehicles, and U.S. Postal Service vehicles did not significantly change from 2017. Flex fuel vehicles or E85-capable vehicles, biodiesel, and renewable diesel vehicles were most often reported for the general public, state fleets, and local fleets. HEVs and PEVs comprised $85 \%$ of commuter vehicles. CNG vehicles made up the largest portion of corporate vehicles at $43 \%$.

$57 \%$ of coalition-reported
vehicles are owned by the
general public and now
have access to alternative
fuel infrastructure
because of Clean Cities
coalition projects.




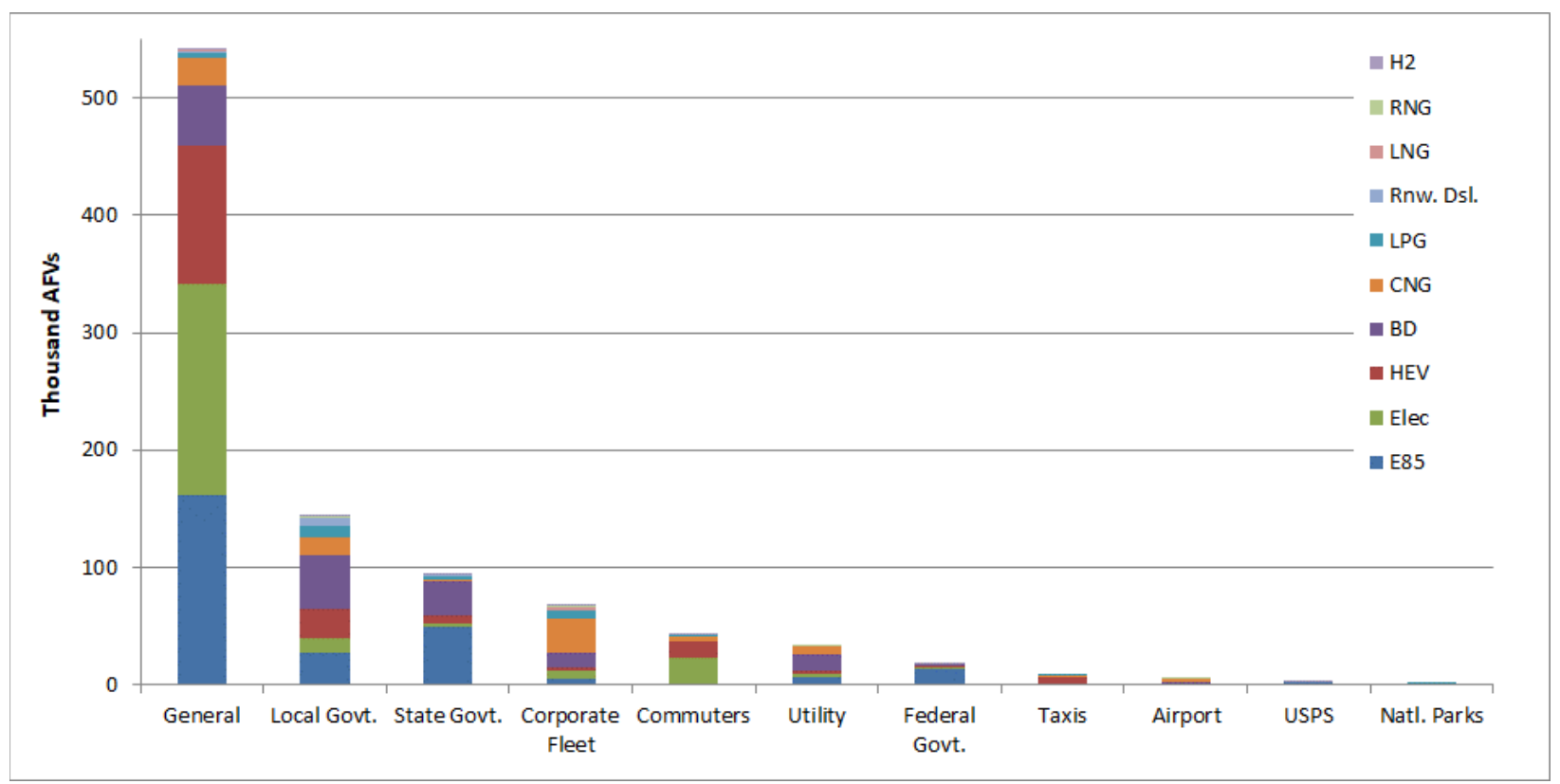

Figure 10. AFVs by application and fuel type

\section{Emerging Technologies-Experimental, Prototype, and Demonstration Vehicle Projects}

A small number of Clean Cities coalitions have worked with fleets and stakeholders who have an interest in field-testing advanced vehicle technologies (e.g., hydrogen and fuel cell vehicles). This subset of vehicles represents just $0.04 \%$ of the total number of alternative fuel or advanced technology vehicles reported by coalitions. Some of these projects involve limited production, experimental, or prototype/demonstration models that are made available from vehicle manufacturers under special lease arrangements. This is a way for the manufacturers to gather inuse performance data, evaluate durability, and refine engineering designs for future vehicle models that may be under development. In 2018, 402 hydrogen vehicles were reported and the largest portion was reported for local government fleets. Data reported to Clean Cities coalitions for some of these vehicles show the noteworthy potential these technologies have for both energy and environmental benefits, but no significant market trends could be drawn from this limited data set.

\section{Coordinators and Coalition Types}

Collectively, coordinators reported spending a total of 2,426 hours per week on Clean Cities coalition tasks, which is equivalent to more than 121,000 total hours during the year. ${ }^{3}$ This translates into 61 fulltime, experienced technical professionals working to increase the use of domestic alternative fuels and reduce wasted energy. For an

The average Clean Cities coordinator has eight years of experience. individual coalition, the average amount of time spent coordinating Clean Cities coalition business per week was 30 hours. The average increased from 29 hours in 2017, while the median remained at 30 hours. The reporting tool also gathered information on coordinator experience.

${ }^{3}$ Assuming 50 work weeks per year. 
Coordinators have been on the job for an average of eight years. Forty-four percent of coordinators have held their position for five years or less. Thirty-seven percent, or 30 coordinators, have 10 years or more of experience.

Coalition types were tracked, and the relationships between coalition type and general metrics were analyzed. The coalition types correspond to their host organizations (which generally pay the coordinator's salary) and are listed in the first column in Table 12 and defined in Appendix B. Standalone nonprofits are coalition types that are self-sustaining and do not operate as part of a larger host organization.

The number of coalitions in each grouping is listed in the second column of Table 12, followed by metrics such as the average number of stakeholders, average funds (including grants and dues) received in 2018, the average GGE of energy impacted, and the average number of persons reached through outreach events. The range of all metrics overlaps heavily between groups, and the low sample size precludes statistical significance. Furthermore, many variables affecting the metrics in this table were not controlled for, so no cause/effect relationships can be inferred between coalition type and specific metrics.

The most common coalition type was standalone nonprofit. University coalitions were the least common type but reported the highest average number of stakeholders. Standalone nonprofits reported the second highest average number of stakeholders, and those reporting the fewest stakeholders were hosted by city and county governments. Coalitions that raised the most funds

Coalitions based in standalone nonprofits were the most successful in terms of EUI, but those hosted in umbrella nonprofits were the most successful at outreach. on average were hosted by city or county governments. University-based coalitions generally brought in the least amount of funding. Standalone nonprofit coalitions had the greatest average EUI. Coalitions that reached the most people in outreach events were hosted nonprofits, which was heavily influenced by a single coalition that reached over 32 million people in press releases. Otherwise, regional governing coalitions, such as metropolitan planning organizations, reached the most people on average. Coalitions hosted by nonprofits generally had the lowest average EUI, and coalitions hosted by city or county governments reached the fewest people.

Table 12. Coalition Metrics by Coalition Type

\begin{tabular}{|l|r|r|r|r|r|}
\hline \multicolumn{1}{|c|}{ Coalition Type a } & $\begin{array}{c}\text { Total \# of } \\
\text { Coalitions }\end{array}$ & $\begin{array}{c}\text { Average \# of } \\
\text { Stakeholders }\end{array}$ & $\begin{array}{c}\text { Average } \\
\text { Funds } \\
\text { Raised }\end{array}$ & $\begin{array}{c}\text { Average } \\
\text { Program } \\
\text { Impact } \\
\text { (GGE) }\end{array}$ & $\begin{array}{c}\text { Average } \\
\text { Persons } \\
\text { Reached }\end{array}$ \\
\hline Nonprofit - Standalone & 33 & 229 & $\$ 1,642,739$ & $14,007,605$ & 47,563 \\
\hline Regional Governing Coalition & 17 & 146 & $\$ 1,614,160$ & $8,149,714$ & 95,561 \\
\hline Nonprofit - Hosted & 11 & 111 & $\$ 13,297,286$ & $6,037,612$ & $2,953,768$ \\
\hline Government - State & 10 & 184 & $\$ 3,233,980$ & $8,621,964$ & 19,462 \\
\hline Government - City or County & 6 & 83 & $\$ 24,258,010$ & $13,105,080$ & 4,495 \\
\hline University & 4 & 603 & $\$ 978,126$ & $8,690,562$ & 7,220 \\
\hline \hline $\begin{array}{l}\text { Total/Overall } \\
\text { Weighted Average }\end{array}$ & $\mathbf{8 1}$ & $\mathbf{1 9 8}$ & $\mathbf{\$ 5 , 0 5 8 , 2 9 2}$ & $\mathbf{1 0 , 7 0 1 , 5 0 9}$ & $\mathbf{4 4 3 , 6 5 5}$ \\
\hline
\end{tabular}

${ }^{a}$ Coalition types are defined in Appendix B. 


\section{Funding}

In 2018, 34 coalitions reported receiving 84 new project awards (project-specific grants) worth a total of over $\$ 211$ million. These coalitions also reported garnering over $\$ 41$ million in leveraged or matching funds for a combined total of nearly $\$ 253$ million in new grant and matching contributions. The value of 26 of the 84 awards met or exceeded $\$ 1$ million each. Table 13 presents a breakdown of the number and value of awards reported by the coalitions without the matching funds.

Table 13. Breakdown of 2018 Project Awards by Number and Value

\begin{tabular}{|l|r|r|r|r|}
\hline \multicolumn{1}{|c|}{ Grant Range } & $\begin{array}{c}\text { Number of } \\
\text { Grants }\end{array}$ & $\begin{array}{c}\text { Share of } \\
\text { Total Number }\end{array}$ & $\begin{array}{c}\text { Share of Grand } \\
\text { Total Value }\end{array}$ & \begin{tabular}{c} 
Tolue \\
\hline$<\$ 50,000$
\end{tabular} \\
43 & $51 \%$ & $\$ 742,579$ & $0.4 \%$ \\
\hline$\$ 50,000-\$ 99,999$ & 5 & $6 \%$ & $\$ 349,900$ & $0.2 \%$ \\
\hline$\$ 100,000-\$ 499,999$ & 6 & $7 \%$ & $\$ 1,432,740$ & $1 \%$ \\
\hline$\$ 500,000-\$ 999,999$ & 4 & $5 \%$ & $\$ 3,388,863$ & $2 \%$ \\
\hline$\$ 1,000,000+$ & 26 & $31 \%$ & $\$ 205,463,912$ & $97 \%$ \\
\hline \hline Total & 84 & $100 \%$ & $\$ 211,377,994$ & $100 \%$ \\
\hline
\end{tabular}

Of the over $\$ 211$ million in primary grant dollars received, $\$ 1.9$ million $(\sim 1 \%)$ was reported as from DOE. State governments were involved in the largest portion of the funding at $(89 \%)$. Other federal contributors included the Department of Transportation's Congestion Mitigation and Air Quality Improvement Program, the U.S. Environmental Protection Agency, and a grouping of other federal agencies. The largest nongovernment contributor was from the Volkswagen settlement with $\$ 2.5$ million (1\%).

In addition to new 2018 awards, coordinators reported the portions of previous multiyear awards spent during the calendar year. If a coordinator failed to report the amount spent during 2018, the total amount of the award divided by the number of years of award duration was assumed. Coalitions reported spending $49 \%$ of the funds they were awarded in 2018, suggesting that projects start quickly after being awarded. In 2018, coalitions used a total of \$137

Coalitions leveraged nearly $\$ 7$ of project funding for every $\$ 1$ directed to coalitions by DOE. million in project funds that were awarded and matched between 2013 and 2018.

In addition to project-related funds, coalitions reported collecting \$1.1 million in stakeholder dues and receiving \$2.9 million in operational funds, primarily from their host organizations. Combining these funds with non-DOE grant and matching funds totaled \$255 million in supplemental non-DOE funds. This total represents nearly 7:1 leveraging of the $\$ 37.8$ million that was included in the VTO Technology Integration budget for FY2018. 


\section{About the Stakeholders}

In 2018,81 coalitions reported a total of 16,014 stakeholders, for an average of 198 stakeholders per coalition, which is more than the average of 150 stakeholders in 2017. Coalitions drew local stakeholders from the public, private, and nonprofit sectors. Stakeholders included local, state, and

Coalitions included 16,014 stakeholders in 2018, with $43 \%$ of them from the private sector. federal government agencies, large and small businesses, auto manufacturers, car dealers, fuel suppliers, public utilities, nonprofits, and professional associations. Coalitions reported that $43 \%$ of stakeholders were from the private sector. This composition is less than the 50\% reported in 2017 but shows a balance between public and private stakeholders.

\section{Data Sources and Quality}

Gathering data is often challenging for coordinators because they rely on voluntary reporting from their numerous stakeholders. Therefore, the annual report website contains some questions related to data sources and quality. In these questions, coordinators were asked to rate the quality of their data as excellent, good, fair, or poor. The "cumulative" bar in Figure 11 presents the response breakdown for the 81 coordinators who answered the question. Thirty-three percent of the respondents classified their data as excellent, $60 \%$ as good, and $6 \%$ as fair. No respondents reported their data as poor.

The reporting tool also asked coordinators how they obtained their data. They could choose one or more of the following: online questionnaires (e.g., Survey Monkey), written (paper or electronic) questions to stakeholders, phone interviews with stakeholders, coalition records, or coalition estimates. Phone interviews and written questions were the most used method of data gathering, accounting for $25 \%$ each. The third most used method was coalition records $(21 \%)$, then estimates (17\%), and finally online questionnaires (12\%). Figure 11 shows that all collection methods resulted in similar levels of reliability. 


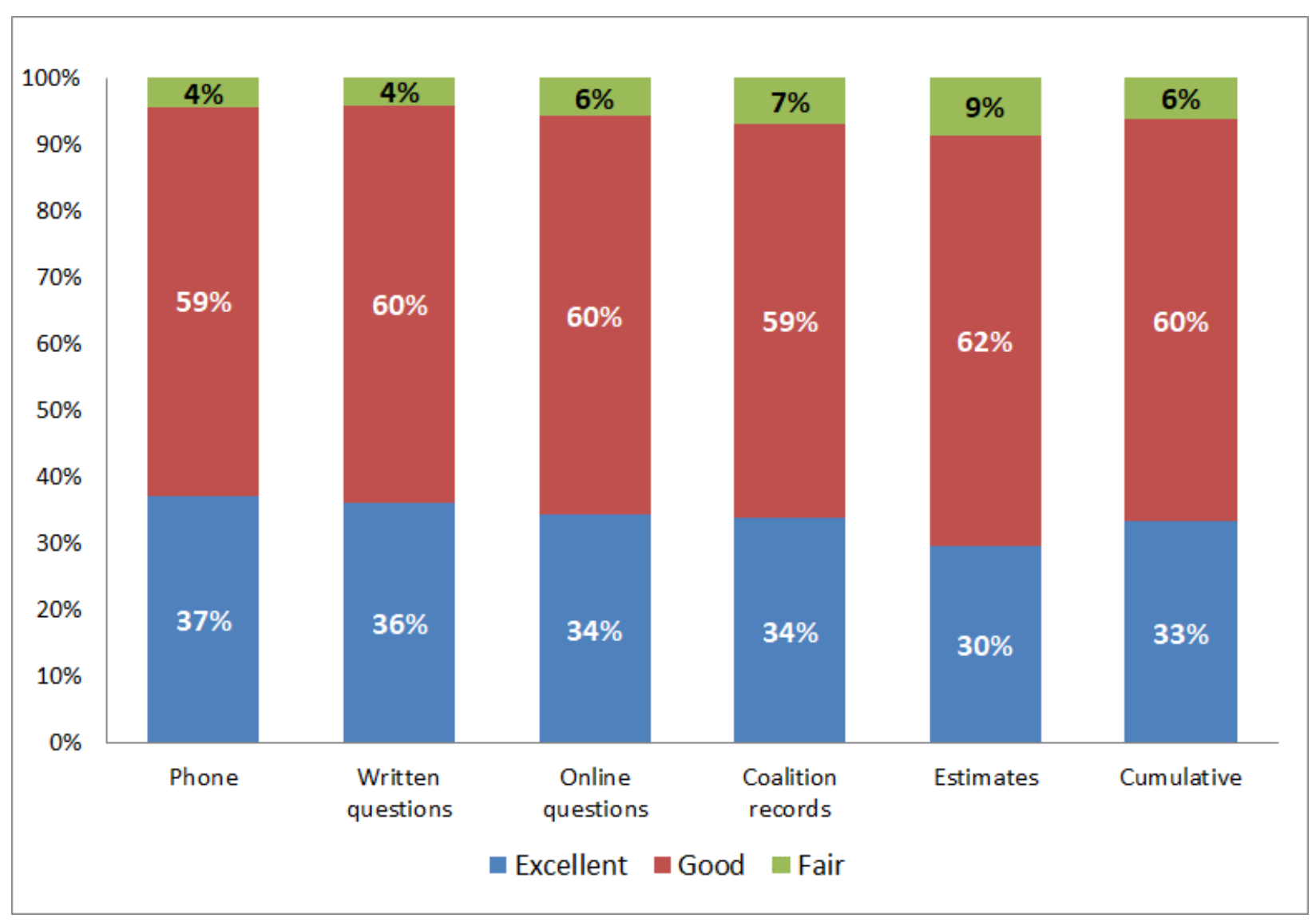

Figure 11. Data quality responses by data source

\section{Conclusion}

The 2018 Clean Cities Coalitions Activity Report helps quantify accomplishments and the impact of the coalitions. The report shows that Clean Cities coalitions had a year of many successful projects. The data indicate that the EUI is over 1 billion GGE for activities reported by coalitions in 2018.

Overall, Clean Cities coalition accomplishments maintained a high level, and improved over last year. Coalition efforts continued to increase the number and diversity of AFVs and advanced vehicles on U.S. roads in 2018. The combined efforts of local Clean Cities coalitions, DOE, and its National Laboratories bring together otherwise disparate groups to leverage people, funding, and resources, to accelerate the nation's progress in increasing domestic fuel use, improving energy security, and reducing emissions. 


\section{Appendix A: Clean Cities Coalitions that Completed 2018 Annual Reports}

\begin{tabular}{|c|c|}
\hline State & Coalition \\
\hline AL & Alabama Clean Fuels Coalition \\
\hline AR & Arkansas Clean Cities \\
\hline$A Z$ & Tucson Clean Cities \\
\hline$A Z$ & Valley of the Sun Clean Cities Coalition (Phoenix) \\
\hline CA & Central Coast Clean Cities \\
\hline CA & Clean Cities Coachella Valley Region \\
\hline CA & East Bay Clean Cities Coalition (Oakland) \\
\hline $\mathrm{CA}$ & Long Beach Clean Cities \\
\hline CA & Los Angeles Clean Cities Coalition \\
\hline CA & Sacramento Clean Cities Coalition \\
\hline CA & San Diego Regional Clean Cities Coalition \\
\hline CA & San Francisco Clean Cities Coalition \\
\hline CA & San Joaquin Valley Clean Cities \\
\hline CA & Silicon Valley Clean Cities (San Jose) \\
\hline CA & Southern California Clean Cities Coalition \\
\hline CA & Western Riverside County Clean Cities Coalition \\
\hline $\mathrm{CO}$ & Denver Metro Clean Cities Coalition \\
\hline $\mathrm{CO}$ & Northern Colorado Clean Cities Coalition \\
\hline $\mathrm{CO}$ & Southern Colorado Clean Cities Coalition \\
\hline CT & Capitol Clean Cities of Connecticut \\
\hline CT & Connecticut Southwestern Area Clean Cities \\
\hline CT & Greater New Haven Clean Cities Coalition \\
\hline DC & Greater Washington Region Clean Cities Coalition \\
\hline DE & State of Delaware Clean Cities \\
\hline $\mathrm{FL}$ & Central Florida Clean Cities Coalition \\
\hline $\mathrm{FL}$ & North Florida Clean Fuels Coalition \\
\hline $\mathrm{FL}$ & Southeast Florida Clean Cities Coalition \\
\hline $\mathrm{FL}$ & Tampa Bay Clean Cities Coalition \\
\hline GA & Clean Cities-Georgia \\
\hline $\mathrm{HI}$ & Sustainable Transportation Coalition of Hawaii \\
\hline IA & lowa Clean Cities Coalition \\
\hline ID & Treasure Valley Clean Cities \\
\hline
\end{tabular}




\begin{tabular}{|c|c|}
\hline State & Coalition \\
\hline ID MT WY & Yellowstone-Teton Clean Cities Coalition \\
\hline IL & Chicago Area Clean Cities \\
\hline IN & Greater Indiana Clean Cities Coalition \\
\hline IN & South Shore Clean Cities \\
\hline KS & Central Kansas Clean Cities \\
\hline KS MO & Kansas City Regional Clean Cities \\
\hline KY & Kentucky Clean Cities Partnership \\
\hline LA & Louisiana Clean Fuels \\
\hline LA & Southeast Louisiana Clean Fuel Partnership \\
\hline MA & Massachusetts Clean Cities \\
\hline MD & State of Maryland Clean Cities \\
\hline ME & Maine Clean Communities \\
\hline MI & Greater Lansing Area Clean Cities \\
\hline $\mathrm{MN}$ & Twin Cities Clean Cities Coalition \\
\hline MO & St. Louis Clean Cities \\
\hline NC & Centralina Clean Fuels Coalition \\
\hline NC & Land of Sky Clean Vehicles Coalition (Western North Carolina) \\
\hline NC & Triangle Clean Cities (Raleigh, Durham, Chapel Hill) \\
\hline ND & North Dakota Clean Cities \\
\hline $\mathrm{NH}$ & Granite State Clean Cities Coalition \\
\hline NJ & New Jersey Clean Cities Coalition \\
\hline NM & Land of Enchantment Clean Cities (New Mexico) \\
\hline NY & Capital District Clean Communities Coalition (Albany) \\
\hline NY & Clean Communities of Central New York (Syracuse) \\
\hline NY & Clean Communities of Western New York (Buffalo) \\
\hline NY & Empire Clean Cities \\
\hline NY & Greater Long Island Clean Cities \\
\hline NY & Greater Rochester Clean Cities \\
\hline $\mathrm{OH}$ & Clean Fuels Ohio \\
\hline OK & Central Oklahoma Clean Cities (Oklahoma City) \\
\hline OK & Tulsa Clean Cities \\
\hline OR & Columbia-Willamette Clean Cities \\
\hline OR & Rogue Valley Clean Cities \\
\hline PA & Eastern Pennsylvania Alliance for Clean Transportation \\
\hline
\end{tabular}




\begin{tabular}{|l|l|}
\hline State & Coalition \\
\hline PA & Pittsburgh Region Clean Cities \\
\hline RI & Ocean State Clean Cities \\
\hline SC & Palmetto Clean Fuels Coalition \\
\hline TN & East Tennessee Clean Fuels Coalition \\
\hline TN & Middle-West Tennessee Clean Fuels Coalition \\
\hline TX & Alamo Area Clean Cities (San Antonio) \\
\hline TX & Dallas-Fort Worth Clean Cities \\
\hline TX & Houston-Galveston Clean Cities \\
\hline TX & Lone Star Clean Fuels Alliance (Central Texas) \\
\hline UT & Utah Clean Cities \\
\hline VA & Virginia Clean Cities \\
\hline VT & Vermont Clean Cities \\
\hline WA & Western Washington Clean Cities \\
\hline WI & Wisconsin Clean Cities \\
\hline WV & State of West Virginia Clean Cities \\
\hline
\end{tabular}




\section{Appendix B: Definition of Clean Cities Coalition Types}

Coalitions have categorized themselves into six different types, depending on their organizational structures and relationship to hosts. ${ }^{4}$ Some coalitions fit within multiple types. These types are as follows:

1. "Government - City or County" coalitions are hosted by a city or county government such as a city department of transportation or municipally owned utility.

2. "Government-State" coalitions are hosted by a state government. This is generally in the state department of energy or department of environment. Coalitions hosted by a state university are not included in this category.

3. "Hosted in a Nonprofit" coalitions are hosted within a larger nonprofit or community service organization with $501 \mathrm{c} 3$ status. The host organization's activities are broader in scope than the Clean Cities coalition, such as the American Lung Association.

4. "Standalone Nonprofit" coalitions are nonprofits typically with 501c3 status and operate with no or minimal oversight and management of a host organization.

5. "Regional Governing Coalition" coalitions are hosted in a multigovernmental body such as a council of governments, municipal planning organization, or regional planning commission.

6. "Hosted in a University" coalitions are hosted by a university (public or private).

\footnotetext{
${ }^{4}$ The relationship between a host organization and the coalition varies across the country. Typically, the coordinator of the coalition is an employee of the host organization, and the coalition benefits from the resources available at the host organization.
} 